\title{
Assessment of Neptunium, Americium, and Curium in the Savannah River Site Environment
}

by

W. H. Carlton

Westinghouse Savannah River Company

Savannah River Site

Aiken, South Carolina 29808

This paper was prepared in connection with work done under the above contract number with the U.S. Department of Energy. By acceptance of this paper, the publisher and/or recipient acknowledges the U. S. Government's right to retain a nonexclusive, royalty-free license in and to any copyright covering this paper, along with the right to reproduce and to authorize others to reproduce all or part of the copyrighted paper. 


\section{DISCLAIMER}

This report was prepared as an account of work sponsored by an agency of the United States Government. Neither the United States Government nor any agency thereof, nor any of their employees, makes any warranty, express or implied, or assumes any legal liability or responsibility for the accuracy, completeness, or usefulness of any information, apparatus, product, or process disclosed, or represents that its use would not infringe privately owned rights. Reference herein to any specific commercial product, process, or service by trade name, trademark, manufacturer, or otherwise does not necessarily constitute or imply its endorsement, recommendation, or favoring by the United States Government or any agency thereof. The views and opinions of authors expressed herein do not necessarily state or reflect those of the United States Government or any agency thereof.

This report has been reproduced directly from the best available copy.

Available to DOE and DOE contractors from the Office of Scientific and Technical Information, P. O. Box 62, Oak Ridge, TN 37831; prices available from (423) 576-8401.

Available to the public from the National Technical Information Service, U. S. Department of Commerce, 5285 Port Royal Road, Springfield, VA 22161. 


\section{DISCLAIMER}

Portions of this document may be illegible electronic image products. Images are produced from the best available original document. 


\section{Assessment of Neptunium, Americium, and Curium in the Savannah River Site Environment (U)}

Westinghouse Savannah River Company

Savannah River Site

Aiken, SC 29808

Prepared for the U.S. Department of Energy under contract no. DE-AC09-96SR18500 


\section{Disclaimer}

This report was prepared as an account of work sponsored by an agency of the United States Government. Neither the United States Government nor any agency thereof, nor any of their employees, makes any warranty, express or implied, or assumes any legal liability or responsibility for the accuracy, completeness, or usefulness of any information, apparatus, product, or process disclosed, or represents that its use would not infringe privately owned rights. Reference herein to any specific commercial product, process, or service by trade name, trademark, manufacturer, or otherwise does not necessarily constitute or imply its endorsement, recommendation, or favoring by the United States Government or any agency thereof. The views and opinions of authors expressed herein do not necessarily state or reflect those of the United States Government or any agency thereof. 
WSRC-TR-97-00266

December 1997

\section{Assessment of Neptunium, Americium, and Curium in the Savannah River Site Environment (U)}

W. H. Carlton

Approved by:

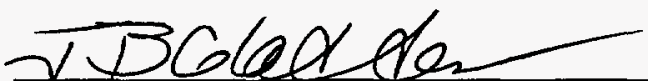

J. B. Gladden, Manager

Environmental Analysis Section

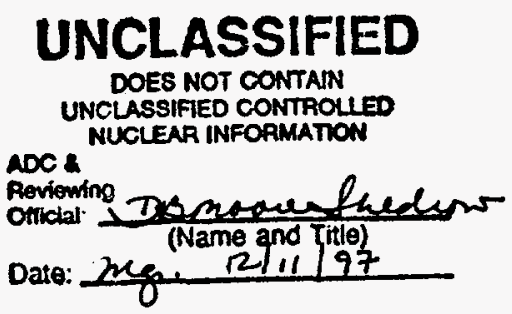

Prepared for the U.S. Department of Energy under contract no. DE-AC09-96SR18500 


\section{Contents}

Executive Summary $i$

Chapter 1. Introduction 1-1

Physical Characteristics 1-3

Radionuclide Monitoring and Reporting 1-3

References 1-3

\section{Chapter 2. Origin and Disposition of Neptunium, Americium, and Curium at SRS 2-1}

Origin of Neptunium, Americium, and Curium at SRS 2-3

Irradiation in Production Reactors 2-3

Medical Grade 238Pu 2-3

Oil Well Logging Neutron Sources 2-3

High Mass Isotopes for Oak Ridge 2-4

Other Sources Due to SRS Operations 2-4

SRS Test Reactors 2-4

Neutron Activation Analysis $2-4$

Materials Originating Offsite $2-4$

Disposition of Neptunium, Americium, and Curium at SRS 2-4

Neptunium, Americium, and Curium in Fuel and Targets Irradiated in Production Reactors 2-4

Neptunium, Americium, and Curium Purchased Offsite 2-5

Neptunium, Americium, and Curium in Certain Fuels Irradiated Offsite $2-5$

Neptunium, Americium, and Curium in Fuel and Targets Irradiated in Test Reactors 2-5

Neutron Activation Analysis Samples 2-6

References 2-6 
Chapter 3. Releases and Stored Inventories of Neptunium, Americium, and Curium at SRS 3-1

Reactor Facilities 3-3

Facility Operations 3-3

Pathways for Release 3-3

Emission Control 3-4

Release Monitoring 3-4

History of Releases 3-4

C Reactor 3-4

K Reactor 3-5

L Reactor 3-5

P Reactor 3-5

R Reactor 3-5

Summary of Reactor Releases 3-5

Separations and Liquid Waste Facilities 3-6

Facility Operations 3-6

Pathways for Release 3-6

Release Monitoring 3-6

History of Measured Relleases 3-7

F-Area Separations 3-6

Releases to Atmosphere 3-7

Releases to Seepage Basins 3-7

H-Area Separations 3-7

Releases to Atmosphere 3-7

Releases to Seepage Basins 3-7

Effluent Treatment Facility 3-7

Waste Tank Farms 3-7

Summary of Separations Releases 3-7

Savannah River Technology Center 3-7

Other Facilities 3-8

References 3-8 
Chapter 4. Assessment of Dose/Risk from SRS Neptunium, Americium, And Curium Releases 4-1

Relationship of Dose to Risk and Health Effects 4-3

lonizing Radiation 4-3

Cancer Risk Estimates 4-3

Neptunium, Americium, and Curium Exposure and Dose to Man 4-3

1. Models of Transport and Dose 4-3

Modeling Atmospheric Dispersion of Radioactive Releases 4-4

MAXIGASP 4-4

POPGASP 4-5

Modeling Doses from Liquid Releases 4-5

Validation of Transport Models

Using Monitoring Data 4-7

Atmospheric Releases 4-7

Liquid Releases 4-7

Impact of SRS Neptunium, Americium, and Curium

Releases on the Offsite Population 4-7

Doses from Atmospheric Releases 4-7

Individual Doses from Liquid Releases 4-9

239Np 4-9

$244 \mathrm{Cm}$ 4-9

Sum of All Doses 4-9

Collective Doses from Liquid Releases 4-9

Comparisons of Neptunium, Americium, and Curium Doses Near SRS with Applicable Regulations 4-10

Atmospheric Releases 4-10

Liquid Releases 4-10

Summary of Dosimetric Impacts 4-10

References 4-11

Additional Reading 4-17 


\section{LIST OF TABLES}

1-1 Physical Characteristics of Neptunium, Americium, and Curium (ICRP 1983) 1-3

3-1 C-Area Releases 3-10

3-2 K-Area Releases 3-10

3-3 L-Area Releases 3-11

3-4 P-Area Releases 3-11

3-5 R-Area Releases 3-12

3-6 F-Area Releases 3-12

3-7 H-Area Releases 3-13

3-8 A-Area Releases 3-14

4-1 Site-Specific Parameters for Atmospheric Releases 4-6

4-2 Site-Specific Parameters for Liquid Releases 4-6

4-3 Additional Site-Specific Parameters

for Liquid Releases 4-7

4-4 Atmospheric Am-241 Releases and Dose 4-13

4-5 Atmospheric Cm-244 Releases and Dose 4-14

4-6 - Stream Releases of Np-239 and Dose 4-15

4-7 Stream Releases of $\mathrm{Cm}-244$ and Dose 4-16

\section{LIST OF FIGURES}

3.1

3.2

3.3

3.4

3.5

3.6

3.7

3.8

3.9

3.10

3.11 .

4.1

4.2
Areas Within SRS That May Be Sources of Neptunium, Americium, and Curium Releases 2-2

Proximity of SRS Facilities to Site Streams 3-2

C-Area Np-239 Releases to Streams 3-15

K-Area Np-239 Releases to Streams 3-15

L-Area Np-239 Releases to Streams 3-16

P-Area Np-239 Releases to Streams 3-16

R-Area Np-239 Releases to Streams 3-17

F-Area Releases to Atmosphere 3-17

F-Area Releases to Basins 3-18

H-Area Releases to Atmosphere 3-19

H-Area Releases to Basins 3-19

A-Area Cm-244 Releases to Atmosphere 3-20

Simplified Pathways between Radioactive Materials

Released to the Atmosphere and Man 4-56

Simplified Pathways between Radioactive Materials

Released to Groundwater or Surface Waters and Man 4-8 


\section{Executive Summary}

A series of documents has been published in which the impact of various radionuclides released to the environment by Savannah River Site (SRS) operations has been assessed. The quantity released, the disposition of the radionuclides in the environment, and the dose to offsite individuals has been presented for activation products, carbon, cesium, iodine, plutonium, selected fission products, strontium, technicium, tritium, uranium, and the noble gases. An assessment of the impact of nonradioactive mercury also has been published.

This document assesses the impact of radioactive transuranics released from SRS facilities since the first reactor became operational late in 1953. The isotopes reported here are ${ }^{239} \mathrm{~Np},{ }^{241} \mathrm{Am}$, and $244 \mathrm{Cm}$.

Release pathways, emission control features, and annual releases to the aqueous and atmospheric environments are discussed. No single incident has resulted in a major acute release of these transuranics to the environment. The releases were the result of normal operations of the reactors and separations facilities. Releases declined over the years as better controls were established, and production was reduced.

The overall radiological impact of SRS neptunium, americium, and curium atmospheric releases between 1954 and 1994 on the offsite maximally exposed individual can be characterized by a total dose of 0.17 mrem. During the same period, such an individual received a total dose of 14,400 mrem from non-SRS sources of ionizing radiation present in the environment. SRS neptunium, americium, and curium aqueous releases between 1954 and 1994 resulted in a total dose of $0.34 \mathrm{mrem}$.

The impact of SRS neptunium, americium, and curium releases on offsite populations also has been evaluated. The total collective dose was estimated as 61 person-rem, distributed among 620,100 individuals. Using international risk factors, far less than one cancer death is predicted from SRS releases, while almost 100,000 fatal cancers will occur in this population from all other causes.

Neptunium, americium, and curium released from SRS present a negligible risk to the offsite environment and the population it supports. 


\section{Chapter 1. Introduction}

Transuranics are those elements with atomic numbers greater than 92, that is, greater than the atomic number of uranium. The Radionuclide Assessment Program (RAP) has reported on the production and release to the environment of one transuranic, plutonium. Other transuranics were produced in the Savannah River Site (SRS) production reactors either during the production of plutonium or during the production of other products such as ${ }^{252} \mathrm{Cf}$. Releases of several transuranics that resulted in dose to the offsite population are discussed in this publication. They are ${ }^{239} \mathrm{~Np},{ }^{241} \mathrm{Am}$, and ${ }^{244} \mathrm{Cm}$. This document will discuss the production, release, migration, and dose to humans for each of these radionuclides. 
This page intentionally left blank. 


\section{Physical Characteristics}

Neptunium-239 decays, with a half-life of 2.4 days, to ${ }^{239} \mathrm{Pu}$ through the emission of a beta particle. Plutonium239 in turn decays, with a half-life of 24,000 years, to ${ }^{235} \mathrm{U}$ through the emission of an alpha particle. Uranium235 eventually ends up as stable ${ }^{207} \mathrm{~Pb}$ after going through a series of 10 daughter products. The common name for this decay process is the Actinium Series.

Americium-241 decays, with a half-life of 430 years, to ${ }^{237} \mathrm{~Np}$ through the emission of an alpha particle. Neptunium-237 eventually ends up as stable ${ }^{209} \mathrm{Bi}$ after going through a series of 11 daughter products. The common name for this decay process is the Neptunium Series.

Curium-244 decays, with a half-life of 18 years, to ${ }^{240} \mathrm{Pu}$ through the emission of an alpha particle. Plutonium-240 decays to ${ }^{236} \mathrm{U}$, which in turn decays to ${ }^{232} \mathrm{Th}$. Thorium232 ends up as stable ${ }^{208} \mathrm{~Pb}$ after going through a series of 10 daughter products. The common name for this decay process is the Thorium Series.

The physical characteristics are summarized in Table 1-1.

\section{Radionuclide Monitoring and Reporting}

SRS releases to the environment have been monitored since startup. In some cases individual radionuclides were identified while in other cases the release was monitored for alpha particle emissions and reported as "gross alpha" or "unidentified alpha". Similarly, measurements were made of "gross beta" or "unidentified beta". In this series of documents, alpha measurements were usually assumed to be ${ }^{239} \mathrm{Pu}$, and beta measurements were assumed to be ${ }^{90} \mathrm{Sr}$. These choices were made because ${ }^{239} \mathrm{Pu}$ and ${ }^{90} \mathrm{Sr}$ are very abundant and also result in relatively high dose per curie released. In this document, doses are calculated only for releases that were identified as ${ }^{239} \mathrm{~Np},{ }^{241} \mathrm{Am}$, or ${ }^{244} \mathrm{Cm}$

\section{References}

ICRP, 1983, International Commission on Radiological Protection, Radionuclide Transformations, Oxford: Pergamon Press; ICRP Publication 38.

Table 1-1. Physical Characteristics of Selected Transuranics (ICRP 1983)

\begin{tabular}{|l|l|l|l|l|}
\hline Radionuclide & \multicolumn{1}{|c|}{ Half-Life } & \multicolumn{1}{|c|}{ Decays to } & Decay Mode & Energy (MeV) \\
\hline \hline & & & & \\
\hline $\mathrm{Np}-239$ & 2.4 days & Pu-239 & Beta & $0.057-0.218^{*}$ \\
\hline & & & & \\
\hline Am-241 & 430 years & Np-237 & Alpha & $5.39-5.54$ \\
\hline & & & & \\
\hline Cm-244 & 18 years & Pu-240 & Alpha & $5.76-5.81$ \\
\hline $\begin{array}{l}\text { Daughter nuclides are radioactive. } \\
\text { *Average beta energy. }\end{array}$ & & & \\
\hline
\end{tabular}




\section{Chapter 2. Origin and Disposition of Neptunium, Americium, and Curium at SRS}

This chapter presents an overview of the origin, uses, and disposition of ${ }^{239} \mathrm{~Np},{ }^{241} \mathrm{Am}$, and ${ }^{244} \mathrm{Cm}$ at SRS under normal operating conditions. The locations of SRS facilities that had the potential to release transuranics are shown in Figure 2.1. The greatest releases to streams occurred during the 1960 s and originated from the reactors, which are located near the center of the 800-square-kilometer site. Atmospheric releases occurred predominantly in A Area and $H$ Area. The history of actual releases from specific SRS facilities is presented in Chapter 3. 


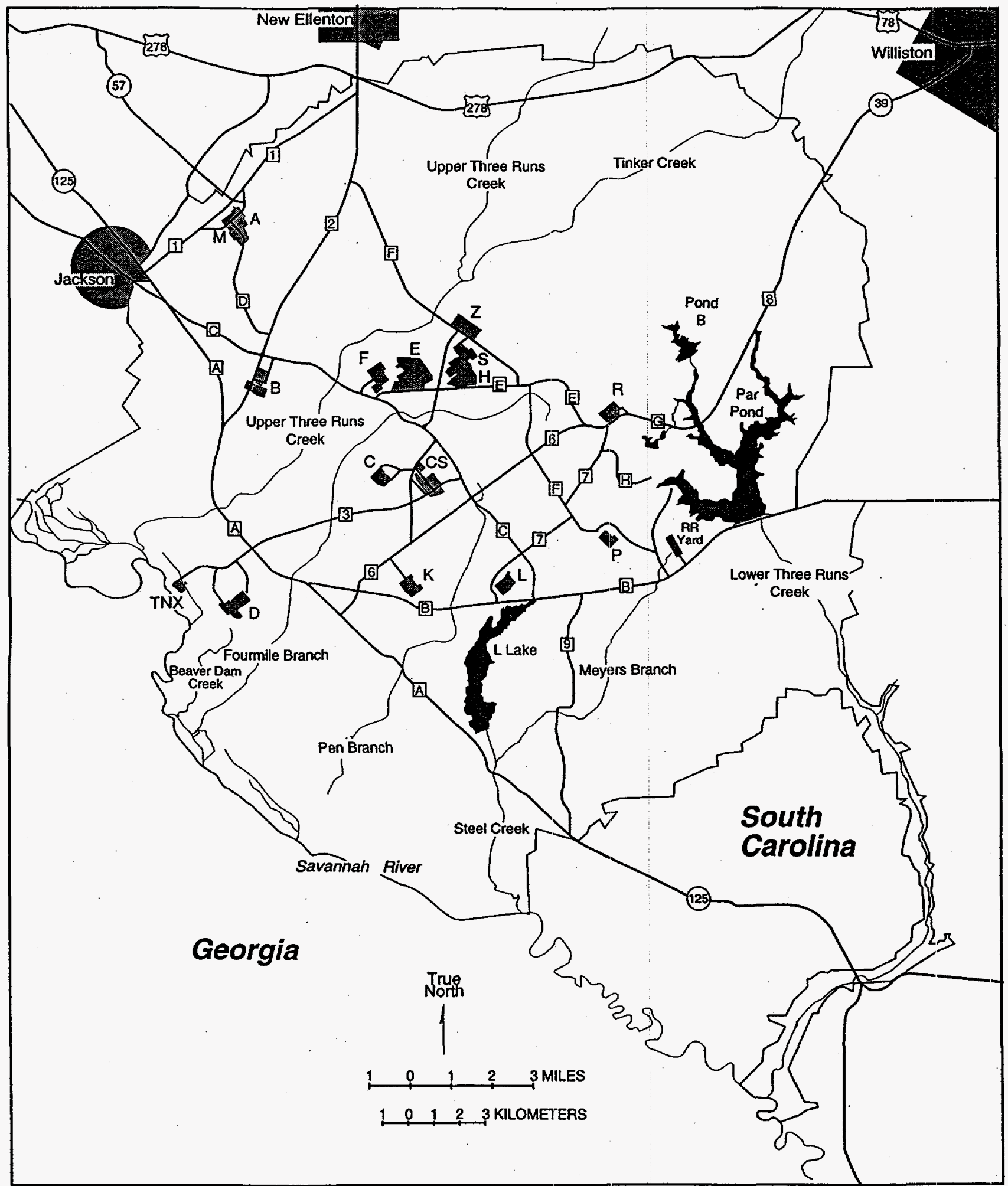

$93 A 030.03$

Figure 2.1. Areas Within SRS That May Be Sources of Neptunium, Americium, and Curium Releases 


\section{Origin of Neptunium, Americium, and Curium at SRS}

Neptunium, americium, and curium at SRS originated predominantly in the fuel and targets that were irradiated in the reactor cores of the Site's five production reactors. Other site operations and offsite sources contributed little to the inventory at SRS.

\section{Irradiation in Production Reactors}

The role of the production reactors was to produce nuclear materials-principally tritium and ${ }^{239} \mathrm{Pu}$-for national defense purposes. Additional radionuclides, such as ${ }^{238} \mathrm{Pu}$, which is a power source for certain deep-space missions, and ${ }^{252} \mathrm{Cf}$, a neutron source used for medical and industrial applications, occasionally were produced for other government purposes.

The reactors became operational in 1953-1955, but they did not operate continuously. They alternated between operating periods of production and periods for maintenance and fuel and target replacement. As of 1997, all five reactors have been placed in cold shutdown. The history of individual reactor operations is discussed in Chapter 3.

The principal mechanism for ${ }^{239} \mathrm{Pu}$ production in the reactors is neutron capture by ${ }^{238} \mathrm{U}$. When a reactor is operating, neutron-induced fission reactions occur in the ${ }^{235} \mathrm{U}$ fuel of the reactor core. In addition to fission products, each neutron-induced fission reaction in the fuel produces several neutrons, some of which induce additional fission reactions and maintain the chain reaction. Some of the remaining neutrons interact with target materials in the reactor. The principal isotope resulting from neutron capture by ${ }^{238} \mathrm{U}$ is ${ }^{239} \mathrm{U}$. The ${ }^{239} \mathrm{U}$ rapidly decays (with a 23.5 minute half-life) to ${ }^{239} \mathrm{~Np}$, which in turn decays (with a 2.4 day half-life) to ${ }^{239} \mathrm{Pu}$. Certain target materials, such as ${ }^{238} \mathrm{U}$, also undergo neutron-induced fission as a competing reaction. Two other significant competing reactions occur in the fuel and target elements. They are significant because they lead to the formation of ${ }^{237} \mathrm{~Np}$, which is the target material for the production of ${ }^{238} \mathrm{Pu}$.

In the fuel, some of the ${ }^{235} U$ captures a neutron to form ${ }^{236} U$. The ${ }^{236} U$ in turn captures a neutron to form ${ }^{237} U$, which decays to ${ }^{237} \mathrm{~Np}$. As ${ }^{235} \mathrm{U}$ is recycled through the irradiation and recovery process, the isotopic fraction of ${ }^{236} \mathrm{U}$ increases, resulting in increasing amounts of ${ }^{237} \mathrm{~Np}$ formation. Neptunium has been recovered in special operations in $\mathrm{H}$ Area and fabricated into targets to produce ${ }^{238} \mathrm{Pu}$. The second reaction producing ${ }^{237} \mathrm{~Np}$ occurred in the ${ }^{238} \mathrm{U}$ targets. In some cases, fission neutrons interacted with the ${ }^{238} \mathrm{U}$ before the neutrons were slowed down by the heavy water moderator. The two principal interactions between ${ }^{238} \mathrm{U}$ and fast neutrons are fission, as mentioned above, and an $(n, 2 n)$ reaction that results in the formation of ${ }^{237} \mathrm{U}$.

Other isotopes of plutonium, especially ${ }^{240} \mathrm{Pu}$ and ${ }^{241} \mathrm{Pu}$, were produced in SRS reactors, principally as unwanted byproducts resulting from neutron capture by ${ }^{239} \mathrm{Pu}$. The ${ }^{240} \mathrm{Pu}$ content was minimized intentionally because of its adverse effect on weapons yield. The ${ }^{241} \mathrm{Pu}$ content was kept low intentionally to minimize buildup of its daughter, ${ }^{241} \mathrm{Am}$. The decay daughters of ${ }^{241} \mathrm{Am}$ emit gamma radiation, which increases personnel exposure during handling and storage of nuclear weapons.

Beginning in 1963, transplutonium isotopes were prepared by placing ${ }^{239} \mathrm{Pu}$ targets in high flux charges in SRS reactors. After the targets were dissolved and processed in a separation facility, they were delivered to SRTC for further processing. The work involved gram quantities of curium and americium, microgram quantities of californium and berkelium, and nanogram quantities of einsteinium. By 1968, approximately $5 \mathrm{~kg}$ of ${ }^{244} \mathrm{Cm}$ had been recovered (Moyer 1968). The ${ }^{244} \mathrm{Cm}$ was used in an experimental program as a heat source for isotopic electrical power generators (Stoddard 1964).

\section{Medical Grade ${ }^{238} \mathrm{Pu}$}

Targets containing ${ }^{241} \mathrm{Am}$ were irradiated in the early 1970 s, producing ${ }^{242} \mathrm{Cm},{ }^{243} \mathrm{Cm}$, and ${ }^{244} \mathrm{Cm}$, in addition to other transuranics. The americium and curium were separated in F Canyon and allowed to stand for 5 months while ${ }^{242} \mathrm{Cm}$ decayed to ${ }^{238} \mathrm{Pu}$. The isotopically pure ${ }^{238} \mathrm{Pu}$ was then separated and shipped to ORNL for various uses, including a heat source to produce electricity for heart pacemakers and reactor dosimeters (Burney and Thompson 1971).

\section{Oil Well Logging Neutron Sources}

Americium-241, produced in the reactors during plutonium production and separated as a waste product, was purified and supplied to other companies for use as an oil well logging source (Gray 1983). The ${ }^{241} \mathrm{Am}$ was mixed 
with beryllium and the ${ }^{241} \mathrm{Am}$ alpha particle knocked a loosely bound neutron from the beryllium nucleus. The number of neutrons reflected back into a neutron detector was related to the organic content of the earth surrounding the source.

\section{High Mass Isotopes for Oak Ridge}

Slugs of ${ }^{242} \mathrm{Pu}$ were irradiated in SRS reactors at high flux $\left(3 \times 10^{15} \mathrm{n} \mathrm{cm}^{-2} \mathrm{~s}^{-1}\right)$ to produce higher mass isotopes for the High Flux Isotopes Reactor (HFIR) at Oak Ridge, Tennessee. Production runs up to $9.3 \times 10^{22} \mathrm{n} \mathrm{cm}^{-2}$ were reported (Banick 1968).

\section{Other Sources Due to SRS Operations}

Minute quantities of neptunium, americium, and curium were produced at SRS by test reactors and neutron activation analysis. The activity levels of these sources were insignificant when compared to activity levels in irradiated nuclear fuel and targets. However, these sources are discussed in the following subsections to provide a complete overview of potential releases.

\section{SRS Test Reactors}

Several small nuclear reactors were in use at two SRS locations from the 1950s through the 1970s. The Heavy Water Components Test Reactor (HWCTR), located in B Area, was used in the early 1960 s to test prototype fuels for a proposed heavy water power reactor. The other test reactors were located in $M$ Area. The Process Development Pile and the Lattice Test Reactor were used as zeropower mock-up facilities to test components for the production reactors. The Subcritical Experimental Pile also was used to test component designs. The Standard Pile provided neutrons for experiments such as neutron radiography and neutron activation. These facilities were used from the mid 1950 s to the late 1970 s.

\section{Neutron Activation Analysis}

Neutron activation analysis is an analytical technique for measurement of elemental compositions in materials. The ${ }^{252} \mathrm{Cf}$ neutron activation facilities and the $\mathrm{C}$ and $\mathrm{K}$ production reactors were used for the analysis of low levels of ${ }^{129} \mathrm{I}$ and uranium. For example, from the late 1970 s to mid 1980s, environmental samples were activated in C Reactor to determine uranium content. Traces of neptunium, americium, and curium were produced in the irradiated uranium samples.

\section{Materials Originating Offsite}

Certain fuel irradiated at offsite non-commercial facilities was shipped to SRS for reprocessing. While awaiting reprocessing, the fuel was stored in the Receiving Basin for Offsite Fuel (RBOF), located in H Area. Depending on the irradiation history, this fuel contained small amounts of neptunium, americium, and curium.

\section{Disposition of Neptunium, Americium, and Curium at SRS}

Because of the association of neptunium, americium, and curium with nuclear weapons material, strict accountability was maintained on the material.

\section{Neptunium, Americium, and Curium in Fuel and Targets Irradiated in Production Reactors}

Under ideal operating conditions, neptunium, americium, and curium were contained within the cladding of fuel and target elements during both irradiation and cooling. Cooling is the interval between the end of irradiation and the beginning of chemical separations. Irradiated materials were stored underwater in reactor basins for most of this time. Beginning in the 1970 s, the cooling time was at least 200 days for most irradiated materials.

Under normal operating conditions, it was possible for traces of neptunium, americium, and curium to escape from irradiated fuel and target elements to the reactor moderator or to the water in the cooling basins through small defects in the cladding. Air and water releases from the reactors were monitored for such possible releases. Actual releases are described in greater detail in Chapter 3.

Occasionally, the small defects developed into holes or splits in the cladding. This was called failure of the element. When a failure occurred, the reactor was shut down, and the failed element was transferred into a container called a "harp". The harp was stored underwater in the reactor basin and vented to the reactor stack. Failures occurred more frequently in the early years of operation than in later years.

A failed element had the potential to contaminate the moderator with reptunium, americium, and curium; SRS reactors used heavy water as a moderator.

Water in the reactor cooling basins also had the potential to become contaminated. Beginning in the 1960 s, basin water routinely was decontaminated by passing the water 
through ion exchange resins to remove most of the radionuclides. Spent resins were reworked in the Resin Regeneration Facility in H Area or buried in the Burial Grounds which was renamed the Solid Waste Disposal Facility (SWDF) in 1990.

After the cooling period, fuel and targets were treated in the chemical separations areas. During the chemical separations process, targets were treated by the Purex process in F Area to recover ${ }^{239} \mathrm{Pu},{ }^{237} \mathrm{~Np}$, and ${ }^{238} \mathrm{U}$ from irradiated ${ }^{238} \mathrm{U}$. The Purex process extracted plutonium and uranium into an organic solvent for separation and purification from waste products. Fuel was treated by the $\mathrm{HM}$ process in $\mathrm{H}$ Area to recover ${ }^{235} \mathrm{U}$ and ${ }^{237} \mathrm{~Np}$ from irradiated ${ }^{235} \mathrm{U}$; until 1959, the Purex process was used in H Area. The principal difference was that the HM process used mercuric nitrate as a catalyst to enhance dissolution of the irradiated fuel. Also in $\mathrm{H}$ Area ${ }^{238} \mathrm{Pu}$ occasionally was recovered from ${ }^{237} \mathrm{~Np}$ targets by the Frames process.

The clarification of dissolver solution and the solvent extraction of uranium, plutonium, and neptunium occurred in process tanks. The vapor space was exhausted to the process vessel vent system and then to the atmosphere through a size-graded sand filter and 61-meter stacks.

Aqueous wastes from the chemical separations processes were evaporated and then sent to underground storage tanks for radioactive waste. Separation of transuranics from the fission products was not complete, so traces of these materials were contained in the waste in storage. The condensate from evaporation of stored liquid waste was sent to the separations area seepage basins until November 1988, when use of the seepage basins was terminated. Miscellaneous aqueous wastes were treated periodically by the evaporation process. Beginning in November 1988, condensate was sent to the Effluent Treatment Facility where it was treated to remove radionuclides and chemicals before being discharged to Upper Three Runs Creek.

During the reprocessing of ${ }^{237} \mathrm{~Np}$ targets in $\mathrm{H}$ Area by the Frames process, offgases from dissolution of cooled ${ }^{237} \mathrm{~Np}$ targets were passed through the sand filter instead of a silver-nitrate reactor before exhausting through the 61-meter stack. This was because the irradiation of ${ }^{237} \mathrm{~Np}$ targets produced much less iodine than the irradiation of ${ }^{235} \mathrm{U}$ fuel.

The Frames process used ion exchange rather than solvent extraction to separate and purify ${ }^{238} \mathrm{Pu}$ and ${ }^{237} \mathrm{~Np}$ from waste products. The treatment for air and aqueous wastes from ion exchange steps is similar to the HM process.
High-level liquid wastes generated in SRTC operations were stored in temporary waste tanks, where short-lived radionuclides decayed to insignificant levels. Periodically, the contents of the waste tanks were shipped to F Area and processed through the waste system. Solid wastes generated in the SRTC handling operations were buried in the SWDF.

Most of the atmospheric and aqueous. effluents in the chemical separations areas and SRTC have been monitored for possible releases. Monitoring techniques and measured releases from the chemical separations areas are described in Chapter 3.

The distributions to the atmosphere, seepage basins, and SWDF had a direct impact on the environment. Transuranics released through stacks were transported through the atmosphere and deposited both onsite and offsite.

\section{Neptunium, Americium, and Curium Purchased Offsite}

Some neptunium, americium, and curium were purchased from offsite vendors. Americium-241 is widely used in smoke detectors for both home and industrial use. Hundreds have been installed at SRS.

Counting room standards are used to calibrate radioactive counting equipment and are disposed of as low-level waste when no longer useful. Sealed sources are accountable sources and usually are kept in secure, shielded vaults when not in use.

\section{Neptunium, Americium, and Curium in Certain Fuels Irradiated Offsite}

Irradiated fuels received from certain offsite facilities were stored underwater in RBOF until the fuel was ready for chemical separations. The fuel then entered the regular process stream in $\mathrm{H}$ Area. The disposition of transuranics became the same as described for fuel irradiated in SRS production reactors.

\section{Neptunium, Americium, and Curium in Fuel and Targets Irradiated in Test Reactors}

Fuels and targets from the various test reactors were sent primarily to the RBOF for cooling before chemical separations. Some were sent to SRTC for research or to reactor materials fabrication facilities. Reactor materials fabrication facilities only received fuel or targets that were not irradiated; this material was blended into the standard fabrication process for targets and fuel to be used in the pro- 
duction reactors. Prior to 1996 , no monitoring for neptunium, americium, and curium was conducted at fabrication facilities.

\section{Neutron Activation Analysis Samples}

Environmental samples were analyzed by high-sensitivity neutron activation for the detection of trace levels of uranium and ${ }^{129} \mathrm{I}$. Typically, the uranium analysis was nondestructive; therefore, any neptunium, americium, and curium produced from fission of uranium was not released. The content was minute, and the samples were disposed in the SWDF as solid radioactive waste.

\section{References}

Banick, C.J.,1968, Americium, Curium, and Plutonium Yields in SRP High Flux Irradiations, DP-1157, E.I. du Pont de Nemours \& Company, Savannah River Laboratory, Aiken, SC.

Burney, G.A., and G.H. Thompson, 1971, Recovery of High Purity $238 P u$ from Irradiated ${ }^{241}$ Am Targets, DPST-71-574, E.I. du Pont de Nemours \& Company, Savannah River Laboratory, Aiken, SC.

Gray, L.W., 1983, Processing of Americium and Curium at Savannah River Plant, DP-MS-83-60, E.I. du Pont de Nemours \& Company, Savannah River Laboratory, A.iken, SC.

Moyer, R.A., 1968, "Savannah River Experience with Transplutonium Elements," Health Physics 15:133138.

Stoddard, D.H.,1964, Radiation Properties of ${ }^{244} \mathrm{Cm}$ Produced for Isotopic Power Generators, DP-939, E.I. du Pont de Nemours \& Company, Savannah River Laboratory, A.iken, SC. 


\section{Chapter 3. Releases and Stored Inventories of Neptunium, Americium, and Curium at SRS}

Routine operations at SRS facilities have released neptunium, americium, and curium to the regional environment surrounding the Site (Cummins et. al 1991a; Cummins et. al 1991b; Amett et. al 1992; Arnett et. al 1993; Arnett et. al 1994; Arnett et. al 1995). Releases have occurred to the atmosphere, seepage basins, and site streams. Releases of ${ }^{239} \mathrm{~Np}$ occurred in the reactor areas, $C, K, L, P$, and $R$, while ${ }^{244} \mathrm{Am}$ and ${ }^{244} \mathrm{Cm}$ were released from $A, F$, and $H$ Areas. The locations of these areas and the site streams are shown in Figure 3.1.

This chapter discusses neptunium, americium, and curium at SRS facilities in terms of possible release pathways, emission control features, and annual releases to the aqueous and atmospheric environments. 


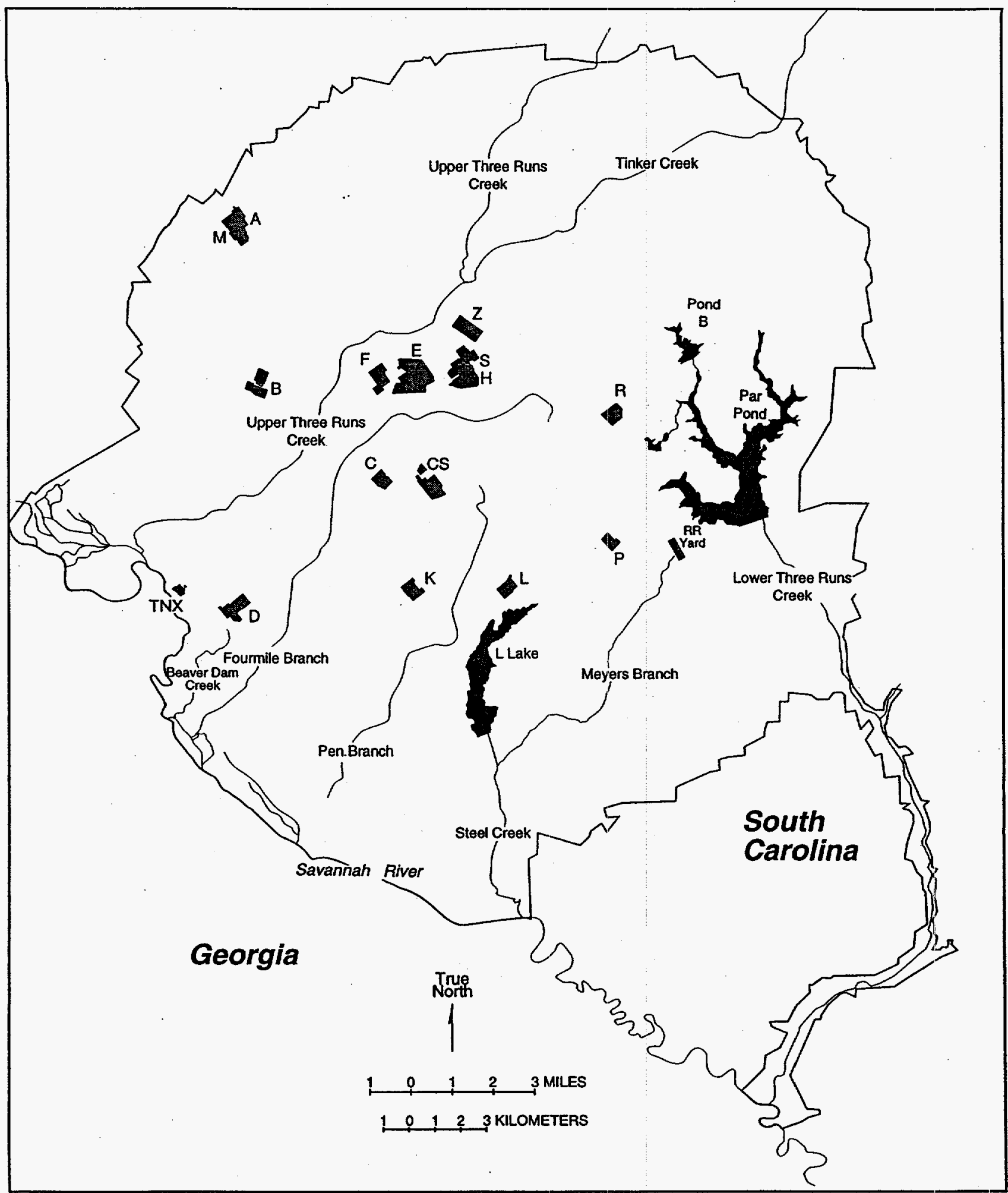

M93A030.04

Figure 3.1. Proximity of SRS Facilities to Site Streams 


\section{Reactor Facilities}

The five production reactors at SRS are identified by the letter designations $C, K, L, P$, and $R$. The reactors were designed to irradiate various targets to produce nuclear materials (principally tritium and plutonium) for national defense purposes. Specific radionuclides for other government purposes also were produced, including ${ }^{238} \mathrm{Pu}$, a power source for certain deep-space missions and ${ }^{252} \mathrm{Cf}$, a neutron source for cancer therapy.

\section{Facility Operations}

When a nuclear reactor was operating, nuclear fission reactions occurred in the reactor core. The principal components of the core were the fuel, targets, control rods, and moderator. Control rods were neutron-absorbing materials positioned in the core to control the power level.

The moderator in SRS reactors was heavy water that was circulated around the fuel and target elements in the reactor core. The moderator decreased the kinetic energy (slowed the speed) of neutrons emitted in the fission process. Slow neutrons are more likely than fast neutrons to interact with fuel and target materials.

The moderator also functioned as the primary coolant to remove heat from fuel and target elements. Heat then was transferred from the moderator to the secondary coolant by heat exchangers. The SRS reactors used either river or pond water as the secondary coolant in the heat exchangers.

In reactors that used water from the Savannah River as the secondary coolant, the river water was passed through the shell side of the heat exchanger and discharged to a site stream that flowed back to the Savannah River. When the $L$ Reactor was upgraded and restarted in the 1980 s, a cooling lake (L Lake) was constructed to mitigate the thermal impact on Steel Creek. River water was pumped through the $L$ Reactor heat exchangers and discharged into $L$ Lake without recirculation. L Lake overflowed into Steel Creek. P and R Reactors used PAR Pond water as the secondary coolant and discharged the water from the heat exchanger to a canal that flowed to a series of cooling ponds. Cooled pond water was recirculated through the heat exchanger.

Under normal operating conditions, fuel and target elements were irradiated for a specified time, removed from the reactor core, and stored underwater in the Vertical
Tube Storage (VTS) basin of the reactor building. Storage in the VTS for the cooling period allowed short-lived radionuclides to decay to low levels before reprocessing of the fuel and targets began. After cooling, the elements were moved to the disassembly basin and prepared for transfer to the chemical separations areas.

\section{Pathways for Release}

During normal reactor operations, traces of neptunium, americium, and curium escaped from irradiated fuel or target elements if a defect developed in the cladding. The defect typically was a micro-scale crack. If a defect developed while the element was in the reactor core, escape from the irradiated material to the moderator was by leaching from the exposed irradiated material.

Circulating moderator and basin water were the primary pathways by which aqueous transuranics were released to the environment. Moderator could have mixed with the secondary coolant if a leak existed in the reactor heat exchanger. Any transuranic releases by this pathway were not specifically quantified; however the secondary coolant was monitored for gross alpha and beta-gamma activity. Leakage to the secondary coolant was a minor pathway compared to the basin water pathway.

Initially, reactor basin waters were purged directly to site streams to remove the heat generated by the stored irradiated fuel and targets. After installation of basin heat exchangers, deionizers, and filters in the 1960 s, the volume of purged water decreased significantly, as did the releases of radioactivity.

Periodic purges were performed to eliminate tritium, the accumulation of which resulted in exposure to operating personnel. Purges were discharged to earthen seepage basins as well as streams. When discharged to streams, the purge water became diluted with much larger volumes of secondary cooling water. Reactor basin discharges to site streams ceased in 1978 and were directed to the reactor seepage basins.

A source of waste water that had low potential for containing neptunium, americium, and curium was the reactor process sewer system. This system received cooling water principally from the shell side of heat exchangers for reactor basins and other miscellaneous process waters. Process sewer water periodically was sampled and analyzed for radionuclides. 
Other waste water was collected in process sumps at the reactor facilities. Occasionally, this waste water contained moderator from leaks that developed during reactor operations or spills that occurred when line breaks were made during maintenance periods. The waste water was collected and analyzed for both radionuclides and moderator content. Possible disposition methods, depending on analytical results, were processing through the Heavy Water Rework Facility or the waste evaporators in the separations areas, or discharging to seepage basins or streams.

The only known mechanism for atmospheric releases of neptunium, americium, and curium from the reactor areas was from resuspension of particulates. All the fuel handling activities for irradiated materials that could contain transuranics were accomplished under water, thus minimizing the likelihood of generation of contaminated particulates or aerosols. All the process-area air from the reactor buildings was routed through HEPA filters before discharge to the atmosphere, further minimizing the likelihood of releases.

\section{Emission Control}

Various measures were implemented to minimize releases of radioactivity. One of these was extensive improvement in the quality of materials fabricated for irradiation. Such improvement minimized the formation of defects in the cladding of fuel and targets.

In the reactor areas, procedural changes were implemented to reduce releases. Provisions were made in 1963 to recirculate basin water through heat exchangers to be cooled and deionized for the removal of radionuclides (except tritium), which considerably reduced discharge volumes. Before 1963, basin water was purged continuously to site streams. Although the deionizers were effective in removing particulates, permanent sand filters were installed in the late 1960 s to maintain water clarity. The residues collected on the sand filters were transported to F Area to be processed and stored in waste tanks. Spent deionizer resin was transported to $\mathrm{H}$ Area for regeneration.

Having accounted for the removal of heat, most radionuclides, and particulates, only the accumulation of tritium prevented the indefinite recirculation of basin water. To reduce tritium exposure to workers in basin areas, basin water periodically was purged to site streams or to reactor seepage basins.

Under normal operating conditions, moderator and some residual radionuclides adhered to fuel and target surfaces when they were removed from the reactor core. In the late 1960s, element flushing during the discharge process was implemented to reduce the adhesion of radioactive mate- rial. Most of the adhered moderator and residual radionuclides were removed. After flushing, the elements were stored in the VTS. The flush water was collected in drums for treatment in the Heavy Water Rework facility.

Atmospheric releases were minimized by using a confinement system intended not only for routine operations, but for a reactor incident. The system consisted of a demister filter bank, a particulate HEPA filter bank, and a carbon filter bank to remove radioiodine.

\section{Release Monitoring}

Reactor stack air was continuously sampled for particulate. radioactivity. Because of the low level of airborne neptunium, americium, and curium in the reactor exhaust air, specific analysis for these radionuclides were not performed. However, the stack air was monitored for gross. alpha and beta-gamma activity

Several techniques were used to monitor aqueous releases. Cooling water was monitored for beta-gamma activity. Basin purge water has been analyzed routinely in the laboratory since the mid 1950s.

Reactor disassembly basin water was tested for ${ }^{239} \mathrm{~Np}$ activity in 1956 and determined to be greater than $50 \%$ of: the total beta-gamma activity in $\mathrm{K}$ and $\mathrm{R}$ Areas. The source of ${ }^{239} \mathrm{~Np}$ was thought to be diffusion out of ${ }^{238} \mathrm{U}$ slugs that had been subjected to neutron irradiation in the reactor (Boni 1956).

Although ${ }^{239} \mathrm{~Np}$ decays to ${ }^{239} \mathrm{Pu}$, the much longer half-life: of ${ }^{239} \mathrm{Pu}$ means that the resulting radioactivity is less than one millionth of the radioactivity of ${ }^{239} \mathrm{~Np}$. It is interesting: to note that the 1956 testing showed no alpha radioactivity (Boni 1956).

\section{History of Releases}

Aqueous releases from each reactor decreased signifi. cantly over the years of operation. Only small quantities of radioactive material were released after recirculation of VTS basin water through sand filters began in the late 1970s. More than $99 \%$ of the ${ }^{239} \mathrm{~Np}$ releases occurred during the 1960s.

\section{Reactor}

C Reactor was operational from 1955 until it was shut down for extensive maintenance in 1985. As of 1997, it is permanently shut down. Reactor basin purges were discharged into Fourmile Branch and three seepage basins, designated 904-66G, -67G, and -68G. The seepage basins were used from 1959 to 1970 and again from 1978 through 1984. Releases to stream and seepage basins from 
Table 3-1 and Figure 3.2. The total measured aqueous releases of activity from $\mathrm{C}$ Reactor during its operational lifetime were 190 curies of ${ }^{239} \mathrm{~Np}$ to Föurmile Branch and 8.1 curies to the seepage basins.

\section{K Reactor}

K Reactor was operational from 1954 until it was shut down in 1988. It was restarted briefly in 1992 and then placed in standby status. As of 1997, it is permanently shut down. Reactor basin purges were discharged to Pen Branch and two basins; a seepage basin designated 90465G and a containment basin designated 904-88G. Because seepage basin 904-65G had poor seepage characteristics, it received disassembly basin purges only in 1959 and 1965. Containment basin $904-88 \mathrm{G}$ was used to receive disassembly basin purges and occasional miscellaneous waste water discharges from 1965 through 1989. Releases to stream and seepage basins from K Area are presented in Table 3-2 and Figure 3.3. The total measured aqueous releases of activity from $\mathrm{K}$ Reactor during its operational lifetime were 130 curies of ${ }^{239} \mathrm{~Np}$ to Fourmile Branch and 1.9 curies to the seepage basins.

\section{Reactor}

L Reactor was operational from 1954 to 1968 , when it was placed in standby. It was refurbished beginning in the early 1980s, restarted in 1985, and operated until 1988. As of 1997 , it is permanently shut down. L Lake was constructed by damming Steel Creek in the early 1980 s to provide thermal mitigation of secondary cooling water from the restarted reactor's heat exchangers. During L Reactor's second operational period, secondary cooling water from the reactor heat exchanger was discharged to L Lake, which drains into Steel Creek.

Reactor basin purges were discharged to Steel Creek, L Lake, and a seepage basin designated 904-64G. The 90464G seepage basin was used intermittently in 1958, 1959, 1961 to 1965,1967 to 1969 , and 1985 through 1989. The L Area Oil and Chemical Basin (904-83G) was used from 1961 to 1979 to receive waste water containing various oils and chemicals from all of the reactor areas. It is adjacent to the 904-64G seepage basin. Releases to stream and seepage basins from K Area are presented in Table 3-3 and Figure 3.4. The total measured aqueous releases of activity from $\mathrm{L}$ Reactor during its operational lifetime were 79 curies of ${ }^{239} \mathrm{~Np}$ to Steel Creek/L Lake and 0.2 curies to the seepage basins.

\section{P Reactor}

P Reactor was operational from 1954 until 1988 when it was shut down. As of 1997, it is permanently shut down. Reactor basin purges were discharged to Steel Creek and PAR Pond during 1954 to 1956,1969 , and 1971 to 1977 . and to three seepage basins during 1957 to 1968,1970 , and 1978 through 1989 . The seepage basins have designations $904-61 \mathrm{G},-62 \mathrm{G}$, and $-63 \mathrm{G}$.

Reactor cooling water and miscellaneous effluents were discharged to Steel Creek until 1963; most of the cooling water later was diverted to PAR Pond. When $L$ Lake was constructed in the early 1980s, all aqueous effluențs were diverted to PAR Pond. Releases to stream and seepage basins from P Area are presented in Table 3-4 and Figure 3.5 . The total measured aqueous releases of activity from $P$ Reactor during its operational lifetime were 200 curies of ${ }^{239} \mathrm{~Np}$ to Steel Creek/PAR Pond and $5.0 \times 10^{-3}$ curies to seepage basins.

\section{R Reactor}

$\mathrm{R}$ Reactor was the first operational production reactor at SRS. It operated from late 1953 until 1964, when it was shut down. Reactor basin water was discharged into Lower Three Runs Creek from 1954 to 1958, into PAR Pond from 1958 to 1964, and also into a seepage basin system from 1957 to 1964 . R Reactor had six seepage basins, designated 904-103G, -104G, -57G, -58G, -59G, and $-60 G$.

The original seepage basin, 904-103G, was used only from June to December 1957. Use of this basin was terminated because of surface outcropping and leakage into an abandoned sewer. The basin was backfilled in 1958 . Basins $904-104 \mathrm{G},-57 \mathrm{G},-58 \mathrm{G}$, and $-59 \mathrm{G}$-in use from 1957 to 1960 -were deactivated, backfilled, and covered with asphalt in 1960. Basin 904-60G-in use from 1958 to 1964 - was backfilled in 1977 .

Reactor heat exchanger cooling water and miscellaneous effluents were discharged to Lower Three Runs Creek from 1954 to 1958. After 1958, these effluents were discharged to PAR Pond. Initially, R-Reactor effluents were discharged directly to PAR Pond. Beginning in 1961, a canal and pond system that eventually drained into PAR Pond (see Figure 3.1) replaced direct discharges into PAR Pond. Releases of ${ }^{23 y} \mathrm{~Np}$ to stream from R Area are presented in Table 3-5 and Figure 3.6. The total measured aqueous releases of ${ }^{239} \mathrm{~Np}$ from R Reactor during its operational lifetime was 830 curies to Lower Three Runs/PAR Pond. There were no recorded releases of ${ }^{239} \mathrm{~Np}$ to seepage basins.

\section{Summary of Reactor Releases}

The total measured stream releases of ${ }^{234} \mathrm{~Np}$ from all five reactors was 1400 curies, and the total measured basin releases was 10 curies. The largest release to streams occurred in 1963. 


\section{Separations and Liquid Waste Facilities}

Two chemical separations facilities and their associated liquid-waste storage facilities are located near the center of the Site (see Figure 3-1). The two separations areas are identified by letter designations $F$ and $H$. In these areas, the products of interest from reactor irradiation are chemically separated and purified from waste products.

\section{Facility Operations}

The two chemical separations facilities were used to reprocess irradiated fuel and targets in canyon buildings (221-F and 221-H). Irradiated materials were dissolved and the products of interest were chemically separated and purified from waste fission and activation products. Occasional special campaigns for production of radionuclides, such as ${ }^{238} \mathrm{Pu}$ and ${ }^{252} \mathrm{Cf}$, have occurred.

Beginning in late $1954,{ }^{239} \mathrm{Pu},{ }^{237} \mathrm{~Np}$, and ${ }^{238} \mathrm{U}$ generally were recovered from irradiated ${ }^{238} \mathrm{U}$ targets in $\mathrm{F}$ Area, which used the Purex chemical extraction process. In $\mathrm{H}$ Area, ${ }^{239} \mathrm{Pu}$ and ${ }^{238} \mathrm{U}$ were recovered from ${ }^{238} \mathrm{U}$ targets by the Purex process during the period 1955-1959. The H-Area facility then was modified to recover ${ }^{235} \mathrm{U}$ from irradiated enriched uranium fuel. A further modification in 1963 allowed the recovery of ${ }^{237} \mathrm{~Np}$ from the fuel; the HM process (H Modified Purex) was used for chemical extraction of the uranium. Also in $\mathrm{H}$ Area, the Frames process was used occasionally to recover ${ }^{238} \mathrm{Pu}$ and ${ }^{237} \mathrm{~Np}$ from special target elements. This process used ion exchange for separation and purification.

Waste facilities in or adjacent to the separations facilities were designed for liquid-waste handling. Depending on activity level, liquid wastes were stored in tanks or sent to seepage basins or the ETF. In November 1988, the ETF became operational to treat the wastes that previously were sent to seepage basins that were closed in 1988 and subsequently decommissioned.

\section{Pathways for Release}

Unlike the reactor facilities, where releases to the environment were almost exclusively through aqueous effluents, the separations facilities releases were through atmospheric and aqueous effluents.
Aqueous releases occurred when residual americium and curium were present in high-level and low-level aqueous waste streams. Before high-level wastes were stored in tanks, an evaporation process was used to reduce volume. During evaporation, some spattering occurred, carrying americium and curium into the condensate from the evaporators. From startup of the separations facilities (1954 for F Area, 1955 for H Area) until 1988, this condensate was sent to the seepage basins. After 1988, the condensate was sent to the ETF. Occasional leaks in cooling-water coils in separations process vessels released small quantities of radioactivity to Fourmile Branch. These leaks had the potential to include americium and curium.

\section{Release Monitoring}

A.tmospheric releases of americium and curium from separations facilities have been measured since shortly after startup. Reprocessing of irradiated material began in F Canyon in November 1954. Continuous sampling was accomplished by passing a portion of stack air through a filter that trapped particulates containing americium and curium as well as other radioactive material. The filter was changed weekly and analyzed for beta and alpha radioactivity. Specific analysis for ${ }^{244} \mathrm{Cm}$ began in 1967 and for ${ }^{241} \mathrm{Am}$ in 1977.

No aqueous releases of neptunium, americium, and curium to streams have been reported. Releases to seepage basins have been quantified since 1977 . Several techniques were used to monitor aqueous releases to stream and basins. Process cooling water in F Area was monitored in-line for beta-gamma and alpha activity. In $\mathrm{H}$ Area, batches of process cooling water were monitored prior to release. When liquid effluents were released to seepage basins, they were continuously sampled. Samples were collected weekly and analyzed for americium and curium content. ETF discharges were sampled prior to release to Upper Three Runs Creek.

\section{History of Measured Releases}

\section{F-Area Separations}

Aqueous wastes from F Canyon initially were sent to waste tanks and a seepage basin designated 90449G, also known as Old F-Area Seepage Basin. The capacity of this basin proved to be inadequate, and it was abandoned in 1955 after three additional seepage basins were constructed. These basins, designated $904-41 G,-42 G$, and $-43 G$, were in use from 1955 until 1988, when waste waters were diverted to 
the ETF. The latter basins also were known as F Seepage Basins 1, 2, and 3.

Additionally, an earthen retention basin (281-3F) was used from 1955 to 1973 for the temporary containment of segregated cooling water potentially contaminated by process upsets. Use of a lined retention basin was implemented in 1973.

\section{Releases to Atmosphere}

The total measured atmospheric release of ${ }^{241} \mathrm{Am}$ from $\mathrm{F}$ Area through 1994 was approximately $4.6 \times 10^{-3}$ curies, and the release of ${ }^{244} \mathrm{Cm}$ was $5.3 \times 10^{-3}$ curies. Measured annual releases are shown in Table 3-6 and Figure 3.7. The maximum annual release of ${ }^{241} \mathrm{Am}, 1.2 \times 10^{-3}$ curies, occurred in 1978, and the maximum annual release of ${ }^{244} \mathrm{Cm}, 8.8 \times 10^{-4}$ curies, occurred in 1980 .

\section{Releases to Seepage Basins}

The total measured release of ${ }^{241} \mathrm{Am}$ to F-Area seepage basins was $2.3 \times 10^{-1}$ curies, and the release of ${ }^{244} \mathrm{Cm}$ was $3.5 \times 10^{-1}$ curies. Measured annual releases are shown in Table 3-6 and Figure 3.8. The maximum annual release of ${ }^{241} \mathrm{Am}, 7.0 \times 10^{-2}$ curies, occurred in 1981 and the maximum annual release of ${ }^{244} \mathrm{Cm}, 7.8 \times 10^{-2}$ curies, occurred in 1973.

\section{H-Area Separations}

H Canyon has been operational since July 1955 . In addition to the general chemical separations operations, $\mathrm{H}$ Area includes the Effluent Treatment Facility and Receiving Basin for Offsite Fuels (RBOF), with an adjacent regeneration facility for resins from other areas. Certain offsite noncommercial irradiated fuels are stored underwater in $R B O F$, as are some SRS fuel elements that have failed. This facility is equipped to disassemble and cut fuel for inspection.

Aqueous wastes from $\mathrm{H}$ Canyon were sent to waste tanks and the four seepage basins designated 904-44G, $-45 \mathrm{G},-46 \mathrm{G}$, and $-56 \mathrm{G}$. The basins, which also were known as $\mathrm{H}$ Seepage Basins 1, 2,3, and 4, were in use from 1955 until 1988, when waste waters were diverted to the ETF. Basin 904-46G had been inactive since 1962.

Also, an earthen retention basin, designated $281-3 \mathrm{H}$, was used from 1955 to 1973 to temporarily contain water potentially contaminated by process upsets. Use of a lined retention basin was implemented in 1973.
Releases to Atmosphere

The total measured atmospheric release of ${ }^{241} \mathrm{Am}$ from $\mathrm{H}$ Area to the atmosphere through 1994 was 1.5 $\times 10^{-3}$ curies and the release of ${ }^{244} \mathrm{Cm} 3.1 \times 10^{-2}$ curies. Measured annual releases are shown in Table 3-7 and Figure 3.9. The maximum annual release of ${ }^{241} \mathrm{Am}, 2.4 \times 10^{-4}$ curies, occurred in 1985 and the maximum annual release of ${ }^{244} \mathrm{Cm}, 3.0 \times 10^{-2}$ curies, occurred in 1967.

\section{Releases to Seepage Basins}

The total measured aqueous release of ${ }^{241} \mathrm{Am}$ to the HArea seepage basins through 1988 was $5.8 \times 10^{-2}$ curies, and the release of ${ }^{244} \mathrm{Cm}$ was $7.3 \times 10^{-2}$ curies. Measured annual releases are shown in Table 3-7 and Figure 3.10. The maximum annual release of ${ }^{241} \mathrm{Am}$, $1.1 \times 10^{-2}$ curies, occurred in 1983, and the maximum annual release of ${ }^{244} \mathrm{Cm}, 1.6 \times 10^{-2}$ curies, occurred in 1974.

\section{Effluent Treatment Facility}

Operation of the ETF was begun in 1988 and no release of neptunium, americium, or curium has been reported.

\section{Waste Tank Farms}

High-level, radioactive, liquid-waste storage tanks, located in F Area and H Area, are known to contain ${ }^{241} \mathrm{Am}$ and ${ }^{244} \mathrm{Cm}$. Most of the radioactivity in these tanks will be transferred to the Defense Waste Processing Facility

\section{Summary of Separations Releases}

Atmospheric releases from $\mathrm{F}$ Area and $\mathrm{H}$ Area totaled $6.1 \times 10^{-3}$ curies of ${ }^{241} \mathrm{Am}$ and $3.6 \times 10^{-2}$ curies of ${ }^{244} \mathrm{Cm}$. Releases to basins totaled $2.9 \times 10^{-1}$ curies of ${ }^{241} \mathrm{Am}$ and $4.2 \times 10^{-1}$ curies of ${ }^{244} \mathrm{Cm}$.

\section{Savannah River Technology Center}

SRTC provided research and development support for SRS production facilities. Laboratory facilities handled radioactivity that ranged from environmental levels to highly radioactive materials. 
Experimental studies using high levels of radioactivity were performed in shielded cells. Air vented from the shielded cells passed through a carbon bed to remove iodine, then through HEPA filters before exhausting from a 15-meter stack. In the early years of operation, a caustic scrubber was used to purify air from the shielded cells. After the 1970s, a sand filter was used before air was vented to a 30-meter stack.

Atmospheric releases of ${ }^{241} \mathrm{Am}$ and ${ }^{244} \mathrm{Cm}$ were periodically reported with the largest releases of ${ }^{244} \mathrm{Cm}$ occurring during the years when research was conducted on its use as a heat source for electricity generation. The total release of ${ }^{241}$ Am was $1.9 \times 10^{-6}$ curies with the maximum occurring in 1992 , and of ${ }^{244} \mathrm{Cm}, 5.3 \times 10^{-2}$ curies with the maximum, $3.2 \times 10^{-2}$ curies, occurring in 1964. Releases to atmosphere are shown in Table 3-8 and Figure 3.11.

Liquid radioactive wastes were accumulated in holding tanks pending shipment to F Area for treatment and disposition. Trade wastes from nonradioactive drains were routed to Tims Branch. Releases to streams occurred during the years when ${ }^{244} \mathrm{Cm}$ research was taking place.

During the period 1969 through 1973, a total of 0.4 curies of ${ }^{244} \mathrm{Cm}$ was released to Tims Branch. The maximum yearly release, 0.3 curies, occurred in 1971 . Releases to streams are shown in Table 3-8.

From 1954 to 1983 , a seepage basin system was used for low-activity wastes. The first two seepage basins, both designated 904-53G, were placed into service in 1954. The last two, 904-54G and -55G, were added in 1958 and 1960. The total quantity of ${ }^{241} \mathrm{Am}$ released to the basins was $7.7 \times$ $10^{-4}$ curies with the maximum annual, $7.1 \times 10^{-4}$ curies, occurring in 1981 . The total quantity of ${ }^{244} \mathrm{Cm}$ released was $5.6 \times 10^{-4}$ curies with the maximum, $5.0 \times 10^{-4}$ curies, occurring in 1981. The basins were taken out of service in 1983. Releases to basins are shown in Table 3-8.

\section{Other Facilities}

All documented neptunium, americium, and curium releases from SRS facilities have been listed in the previous sections. A number of other facilities handled materials potentially containing small quantities. These were the test reactors, the Heavy Water Rework Facility and the heat exchanger repair facility in Central Shops.
No releases of alpha activity are documented from any of the test reactors. These facilities were operated at essentially zero-power level, and the risk of release of neptunium, americium, and curium from the elements being tested was minimal.

The Heavy Water Rework Facility, located in D Area, consisted of distillation towers and associated equipment to remove ordinary water that accumulated in the heavy water moderator used in the reactors. Leaks in the system were vented through a 21-meter stack. The aqueous waste stream was sent to Beaver Dam Creek after verification that activity levels did not exceed specific limits. The predominant radioactivity associated with this facility was tritium.

Potential existed for traces of neptunium, americium, and curium to be present in the moderator, as was described in the section on reactor facilities. No specific monitoring for these radionuclides was performed because of the extremely low potential for a release. However, gross alpha and beta-gamma monitoring were performed.

Central Shops at SRS fabricated and repaired equipment used in the separations and reactor areas. Although equipment was decontaminated before it was sent to Central Shops, some radioactive material occasionally was present and normally was removed during cleaning before the equipment was repaired. The contamination was transferred with other liquid waste streams to a seepage basin.

\section{References}

Arnett, M.W., L.K. Karapatakis, and A.R. Mamatey, 1993, Savannah River Site Environmental Report for 1992, WSRC-TR-93-075, Westinghouse Savannah River Company, Aiken, SC.

Arnett, M.W., L.K. Karapatakis, and A.R. Mamatey, 1994, Savannah River Site Environmental Report for 1993, WSRC-TR-94-075, Westinghouse Savannah River Company, Aiken, SC.

Arnett, M.W., L.K. Karapatakis, A.R. Mamatey, and J.L. Todd, 1992, Savannah River Site Environmental Report for 1991, WSRC-TR-92-186, Westinghouse Savannah River Company, Aiken, SC.

Arnett, M.W., A.R. Mamatey, and D. Spitzer, 1995, Savannah River Site Environmental Report for 1994, WSRC-TR-95-075, Westinghouse Savannah River Company, Aiken, SC. 
Chapter 3. Releases and Stored Inventories of Neptunium, Americium, and Curium at SRS

Boni, A.L., 1956, Neptunium-239 in Disassembly Basin Water, DPSP-56-25-58, E. I. du Pont de Nemours \& Company, Savannah River Laboratory, Aiken, SC.

Cummins, C.L., D.K. Martin, and J.L. Todd, 1991a, Savannah River Site Environmental Report, 1990, WSRC-IM-91-28, Westinghouse Savannah River Company, Aiken, SC.

Cummins, C.L., C.S. Hetrick, and D.K. Martin, 1991b, Radioactive Releases at the Savannah River Site 1954-1989, WSRC-RP-91-684, Westinghouse Savannah River Company, Aiken, SC. 
Table 3-5. R-Area Releases

\begin{tabular}{|c|c|}
\hline Year & $\begin{array}{c}\text { Releases to } \\
\text { Streams (Ci) } \\
\mathrm{Np}-239\end{array}$ \\
\hline 1954 & \\
\hline 1955 & \\
\hline 1956 & \\
\hline 1957 & \\
\hline 1958 & \\
\hline 1959 & \\
\hline 1960 & $1.5 \times 10^{1}$ \\
\hline 1961 & $1.2 \times 10^{1}$ \\
\hline 1962 & $1.8 \times 10^{I}$ \\
\hline 1963 & $6.8 \times 10^{2}$ \\
\hline 1964 & $1.0 \times 10^{2}$ \\
\hline 1965 & \\
\hline 1966 & \\
\hline 1967 & \\
\hline 1968 & \\
\hline 1969 & \\
\hline 1970 & \\
\hline 1971 & \\
\hline 1972 & \\
\hline 1973 & \\
\hline 1974 & \\
\hline 1975 & \\
\hline 1976 & \\
\hline 1977 & \\
\hline 1978 & \\
\hline 1979 & \\
\hline 1980 & \\
\hline 1981 & \\
\hline 1982 & \\
\hline 1983 & \\
\hline 1984 & . \\
\hline 1985 & \\
\hline 1986 & \\
\hline 1987 & \\
\hline 1988 & \\
\hline 1989 & \\
\hline 1990 & \\
\hline 1991 & \\
\hline 1992 & \\
\hline 1993 & \\
\hline 1994 & \\
\hline Total & $8.3 \times 10^{2}$ \\
\hline
\end{tabular}

Table 3-6. F-Area Releases

\begin{tabular}{|c|c|c|c|c|}
\hline \multirow{2}{*}{ Year } & \multicolumn{2}{|c|}{ Releases to Atmosphere (Ci) } & \multicolumn{2}{|c|}{ Releases to Basins (Ci) } \\
\hline & Am-241 & $\mathrm{Cm}-244$ & Am-2A1 & $\mathrm{Cm}-244$ \\
\hline \multicolumn{5}{|l|}{1954} \\
\hline \multicolumn{5}{|l|}{1955} \\
\hline \multicolumn{5}{|l|}{1956} \\
\hline \multicolumn{5}{|l|}{1957} \\
\hline \multicolumn{5}{|l|}{1958} \\
\hline \multicolumn{5}{|l|}{1959} \\
\hline \multicolumn{5}{|l|}{1960} \\
\hline \multicolumn{5}{|l|}{1961} \\
\hline \multicolumn{5}{|l|}{1962} \\
\hline \multicolumn{5}{|l|}{1963} \\
\hline \multicolumn{5}{|l|}{1964} \\
\hline \multicolumn{5}{|l|}{1965} \\
\hline \multicolumn{5}{|l|}{1966} \\
\hline \multicolumn{5}{|l|}{1967} \\
\hline \multicolumn{5}{|l|}{1968} \\
\hline \multicolumn{5}{|l|}{1969} \\
\hline 1970 & & $5.0 \times 10^{-4}$ & & \\
\hline 1971 & & $7.0 \times 10^{-4}$ & & \\
\hline 1972 & & $1.1 \times 10^{-4}$ & & \\
\hline 1973 & & $3.4 \times 10^{-4}$ & & $7.8 \times 10^{-2}$ \\
\hline 1974 & & $3.9 \times 10^{-4}$ & & $2.3 \times 10^{-2}$ \\
\hline \multicolumn{5}{|l|}{1975} \\
\hline 1976 & & $2.6 \times 10^{-4}$ & & $2.1 \times 10^{-2}$ \\
\hline 1977 & $1.5 \times 10^{-4}$ & $1.5 \times 10^{-4}$ & $2.0 \times 10^{-3}$ & $3.7 \times 10^{-2}$ \\
\hline 1978 & $1.2 \times 10^{-3}$ & $7.2 \times 10^{-5}$ & $2.1 \times 10^{-2}$ & $4.0 \times 10^{-3}$ \\
\hline 1979 & $2.8 \times 10^{-4}$ & $3.3 \times 10^{-4}$ & $4.7 \times 10^{-2}$ & $4.7 \times 10^{-2}$ \\
\hline 1980 & $1.0 \times 10^{-3}$ & $8.8 \times 10^{-4}$ & $2.0 \times 10^{-2}$ & $8.0 \times 10^{-3}$ \\
\hline 1981 & $2.9 \times 10^{-4}$ & $9.3 \times 10^{-5}$ & $7.0 \times 10^{-2}$ & $2.9 \times 10^{-2}$ \\
\hline 1982 & $3.7 \times 10^{-4}$ & $1.3 \times 10^{-4}$ & $1.7 \times 10^{-2}$ & $7.1 \times 10^{-3}$ \\
\hline 1983 & $1.5 \times 10^{-4}$ & $4.6 \times 10^{-4}$ & $5.3 \times 10^{-3}$ & $9.6 \times 10^{-3}$ \\
\hline 1984 & $1.1 \times 10^{-4}$ & $2.1 \times 10^{-4}$ & $2.0 \times 10^{-2}$ & $2.5 \times 10^{-2}$ \\
\hline 1985 & $1.9 \times 10^{-4}$ & $2.2 \times 10^{-4}$ & $1.4 \times 10^{-2}$ & $2.4 \times 10^{-2}$ \\
\hline 1986 & $6.9 \times 10^{-5}$ & $2.3 \times 10^{-5}$ & $9.0 \times 10^{-3}$ & $2.6 \times 10^{-2}$ \\
\hline 1987 & $1.5 \times 10^{-4}$ & $3.1 \times 10^{-4}$ & $3.3 \times 10^{-3}$ & $5.0 \times 10^{-3}$ \\
\hline 1988 & $6.9 \times 10^{-5}$ & $6.3 \times 10^{-5}$ & $2.3 \times 10^{-3}$ & $2.9 \times 10^{-3}$ \\
\hline 1989 & $1.7 \times 10^{-4}$ & $2.6 \times 10^{-5}$ & & \\
\hline 1990 & $8.3 \times 10^{-5}$ & $1.1 \times 10^{-5}$ & & \\
\hline 1991 & $1.1 \times 10^{-4}$ & $9.1 \times 10^{-6}$ & & \\
\hline 1992 & $6.4 \times 10^{-5}$ & $7.8 \times 10^{-6}$ & & \\
\hline 1993 & $6.1 \times 10^{-5}$ & $4.3 \times 10^{-5}$ & & \\
\hline 1994 & $5.1 \times 10^{-5}$ & $1.1 \times 10^{-5}$ & & \\
\hline Total & $4.6 \times 10^{-3}$ & $5.3 \times 10^{-3}$ & $2.3 \times 10^{-1}$ & $3.5 \times 10^{-1}$ \\
\hline
\end{tabular}


Table 3-7. H-Area Releases

\begin{tabular}{|c|c|c|c|c|}
\hline \multirow{2}{*}{ Year } & \multicolumn{2}{|c|}{ Releases to Atmosphere (Ci) } & \multicolumn{2}{|c|}{ Releases to Basins (Ci) } \\
\hline & Am-241 & $\mathrm{Cm}-244$ & Am-241 & $\mathrm{Cm}-244$ \\
\hline \multicolumn{5}{|l|}{1954} \\
\hline \multicolumn{5}{|l|}{1955} \\
\hline \multicolumn{5}{|l|}{1956} \\
\hline \multicolumn{5}{|l|}{1957} \\
\hline \multicolumn{5}{|l|}{1958} \\
\hline \multicolumn{5}{|l|}{1959} \\
\hline \multicolumn{5}{|l|}{1960} \\
\hline \multicolumn{5}{|l|}{1961} \\
\hline \multicolumn{5}{|l|}{1962} \\
\hline \multicolumn{5}{|l|}{1963} \\
\hline \multicolumn{5}{|l|}{1964} \\
\hline \multicolumn{5}{|l|}{1965} \\
\hline \multicolumn{5}{|l|}{1966} \\
\hline 1967 & & $3.0 \times 10^{-2}$ & & \\
\hline \multicolumn{5}{|l|}{1968} \\
\hline \multicolumn{5}{|l|}{1969} \\
\hline \multicolumn{5}{|l|}{1970} \\
\hline \multicolumn{5}{|l|}{1971} \\
\hline 1972 & & $1.9 \times 10^{-4}$ & & \\
\hline 1973 & & $2.0 \times 10^{-5}$ & & $1.5 \times 10^{-2}$ \\
\hline 1974 & & & & $1.6 \times 10^{-2}$ \\
\hline \multicolumn{5}{|l|}{1975} \\
\hline 1976 & & $7.0 \times 10^{-5}$ & & $5.0 \times 10^{-3}$ \\
\hline 1977 & $1.9 \times 10^{-4}$ & $1.9 \times 10^{-4}$ & $1.0 \times 10^{-2}$ & $1.0 \times 10^{-2}$ \\
\hline 1978 & $6.6 \times 10^{-5}$ & $6.6 \times 10^{-5}$ & $6.0 \times 10^{3}$ & $6.0 \times 10^{-3}$ \\
\hline 1979 & $7.1 \times 10^{-5}$ & $6.3 \times 10^{-5}$ & $1.5 \times 10^{-3}$ & $1.5 \times 10^{-3}$ \\
\hline 1980 & $3.4 \times 10^{-5}$ & $2.0 \times 10^{-5}$ & $3.0 \times 10^{-3}$ & $2.0 \times 10^{-3}$ \\
\hline 1981 & $2.0 \times 10^{-4}$ & $7.0 \times 10^{-5}$ & $3.4 \times 10^{-3}$ & $1.2 \times 10^{-3}$ \\
\hline 1982 & $1.2 \times 10^{-4}$ & $3.5 \times 10^{-5}$ & $2.5 \times 10^{-3}$ & $1.2 \times 10^{-3}$ \\
\hline 1983 & $1.1 \times 10^{-4}$ & $4.6 \times 10^{-5}$ & $1.1 \times 10^{-2}$ & $4.8 \times 10^{-3}$ \\
\hline 1984 & $3.0 \times 10^{-5}$ & $4.7 \times 10^{-5}$ & $4.0 \times 10^{-3}$ & $4.0 \times 10^{-3}$ \\
\hline 1985 & $2.4 \times 10^{-4}$ & $2.6 \times 10^{-5}$ & $9.0 \times 10^{-3}$ & $4.0 \times 10^{-3}$ \\
\hline 1986 & $8.5 \times 10^{-5}$ & $5.0 \times 10^{-6}$ & $2.9 \times 10^{-3}$ & $7.6 \times 10^{-4}$ \\
\hline 1987 & $5.6 \times 10^{-5}$ & $1.4 \times 10^{-5}$ & $3.6 \times 10^{-3}$ & $9.8 \times 10^{-4}$ \\
\hline 1988 & $4.9 \times 10^{-5}$ & $4.0 \times 10^{-6}$ & $1.0 \times 10^{-3}$ & $4.5 \times 10^{-4}$ \\
\hline 1989 & $3.1 \times 10^{-5}$ & $2.0 \times 10^{-6}$ & & \\
\hline 1990 & $4.5 \times 10^{-5}$ & $7.4 \times 10^{-6}$ & & \\
\hline 1991 & $4.3 \times 10^{-5}$ & $3.3 \times 10^{-5}$ & & \\
\hline 1992 & $4.9 \times 10^{-5}$ & $1.5 \times 10^{-5}$ & & \\
\hline 1993 & $8.1 \times 10^{-5}$ & $6.5 \times 10^{-6}$ & & \\
\hline 1994 & $5.2 \times 10^{-6}$ & $1.6 \times 10^{-6}$ & & \\
\hline Total & $1.5 \times 10^{-3}$ & $3.1 \times 10^{-2}$ & $5.8 \times 10^{-2}$ & $7.3 \times 10^{-2}$ \\
\hline
\end{tabular}


Table 3-8. A-Area Releases

\begin{tabular}{|c|c|c|c|c|c|}
\hline \multirow[t]{2}{*}{ Year } & \multicolumn{2}{|c|}{ Releases to Atmosphere (Ci) } & \multirow{2}{*}{$\begin{array}{c}\text { Release to } \\
\text { Streams (Ci) } \\
\text { Cm-244 }\end{array}$} & \multicolumn{2}{|c|}{ Releases to Basins (Ci) } \\
\hline & Am-241 & $\mathrm{Cm}-244$ & & $\mathrm{Am}-241$ & $\mathrm{Cm}-244$ \\
\hline 1954 & & & . & & \\
\hline 1955 & & & & & \\
\hline 1956 & & & & & \\
\hline 1957 & & & & & \\
\hline 1958 & & & & & \\
\hline 1959 & & & & & \\
\hline 1960 & & & & & \\
\hline 1961 & & & & & \\
\hline 1962 & & & & & \\
\hline 1963 & & & & & \\
\hline 1964 & & $3.2 \times 10^{-2}$ & & & \\
\hline 1965 & & & & & \\
\hline 1966 & & & & & \\
\hline 1967 & & & & & \\
\hline 1968 & & & & & \\
\hline 1969 & & $2.1 \times 10^{-2}$ & $3.0 \times 10^{-2}$ & & \\
\hline 1970 & & $4.1 \times 10^{-4}$ & & & \\
\hline 1971 & & & $3.2 \times 10^{-1}$ & & \\
\hline 1972 & & $9.0 \times 10^{-5}$ & $2.8 \times 10^{-2}$ & & \\
\hline 1973 & & $1.9 \times 10^{-5}$ & $3.6 \times 10^{-3}$ & & \\
\hline 1974 & & & & & \\
\hline 1975 & & & & & \\
\hline 1976 & & & & & \\
\hline 1977 & & & & & \\
\hline 1978 & & & & & \\
\hline 1979 & & & & $5.8 \times 10^{-5}$ & $5.8 \times 10^{-5}$ \\
\hline 1980 & & & & & \\
\hline 1981 & & & & $7.1 \times 10^{-4}$ & $5.0 \times 10^{-4}$ \\
\hline 1982 & & & & & \\
\hline 1983 & & & & & \\
\hline 1984 & & & & & \\
\hline 1985 & & & & & \\
\hline 1986 & & & & & \\
\hline 1987 & & & & & \\
\hline 1988 & & & & & \\
\hline 1989 & $2.4 \times 10^{-7}$ & & & & \\
\hline 1990 & & $2.1 \times 10^{-6}$ & & & \\
\hline 1991 & $2.3 \times 10^{-8}$ & & & & \\
\hline 1992 & $1.3 \times 10^{-6}$ & $7.9 \times 10^{-8}$ & & & \\
\hline 1993 & $2.8 \times 10^{-7}$ & $6.8 \times 10^{-6}$ & & & \\
\hline 1994 & & $3.9 \times 10^{-6}$ & & & \\
\hline Total & $1.9 \times 10^{-6}$ & $5.3 \times 10^{-2}$ & $3.9 \times 10^{-1}$ & $7.7 \times 10^{-4}$ & $5.6 \times 10^{-4}$ \\
\hline
\end{tabular}




\section{Figure 3.2. C-Area Np-239 Releases to Streams}

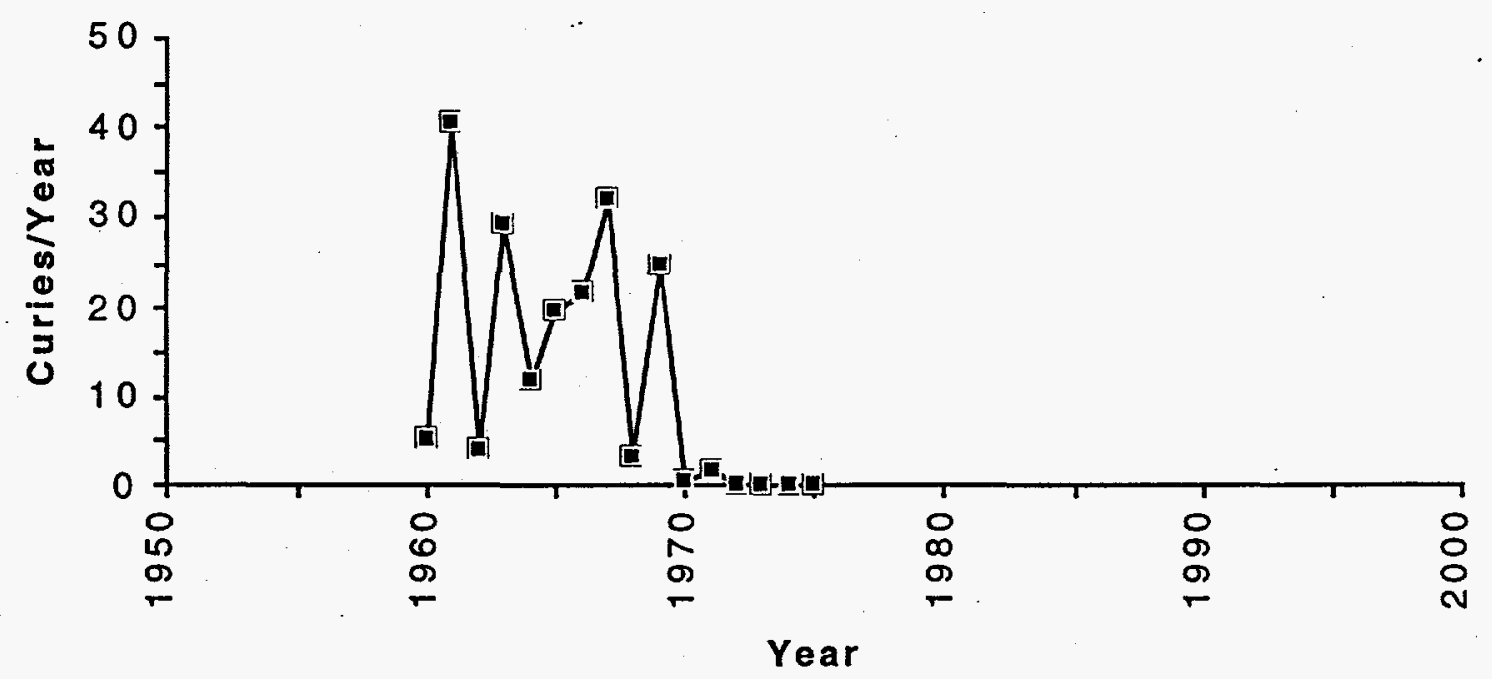

Figure 3.3. K-Area Np-239 Releases to Streams

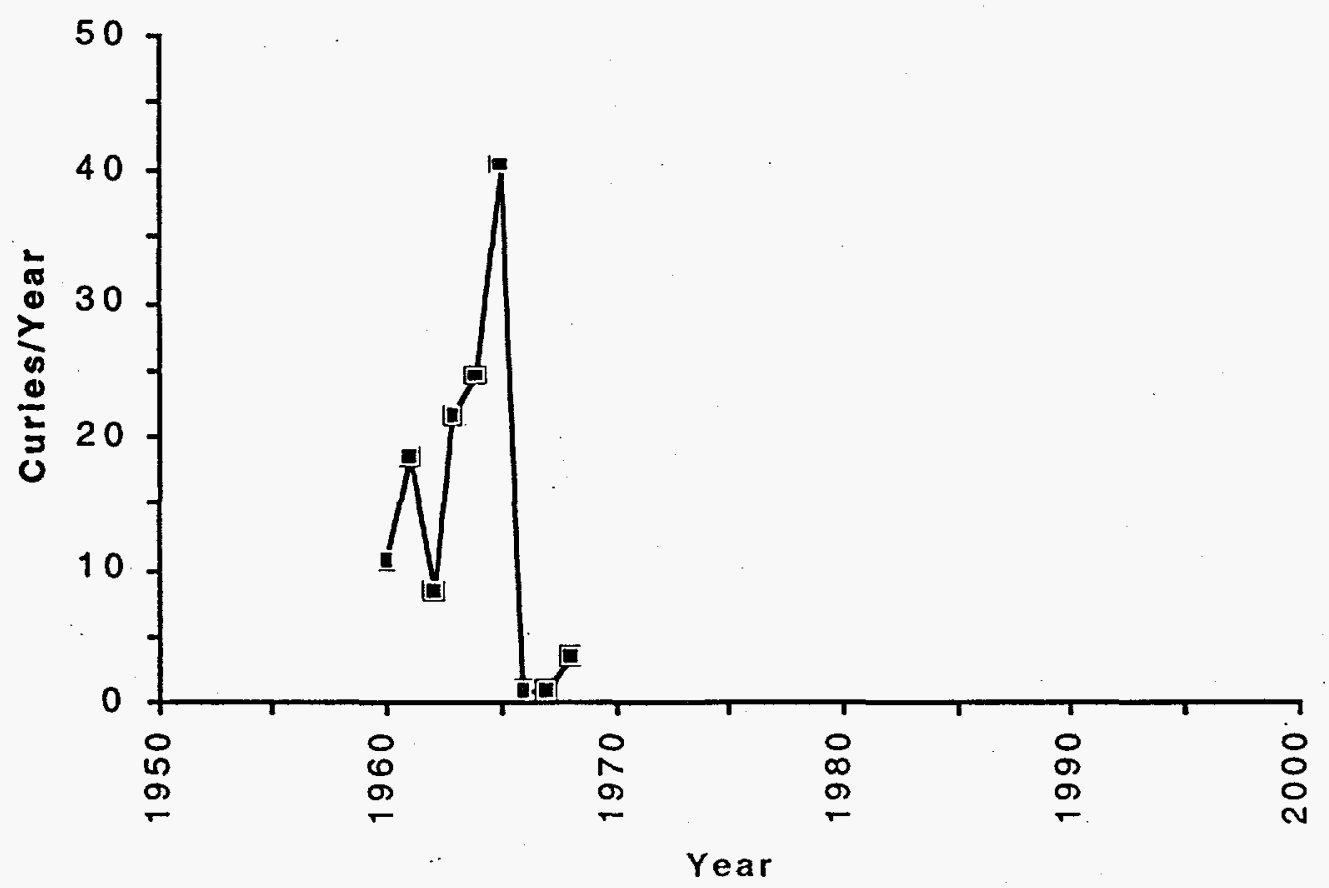


Figure 3.4. L-Area Np-239 Releases to Streams

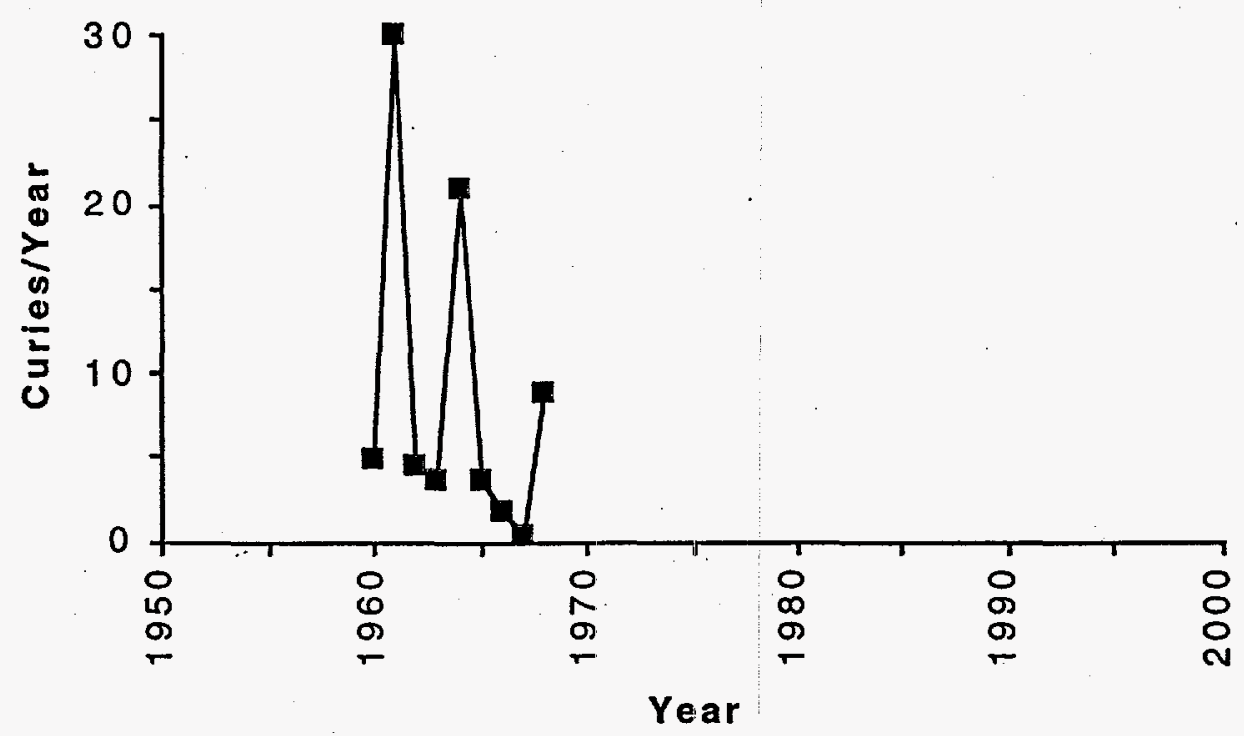

Figure 3.5. P-Area Np-239 Releases to Streams

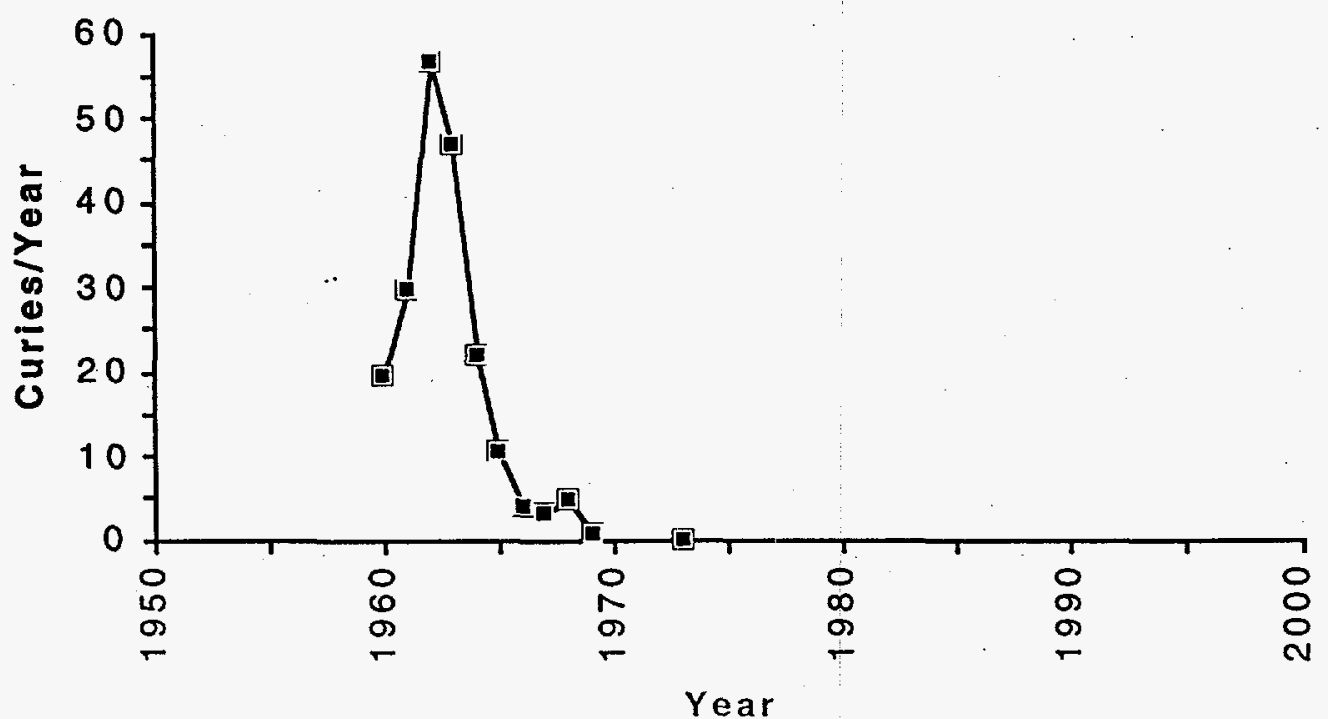


Figure 3.6. R-Area Np-239 Releases to Streams

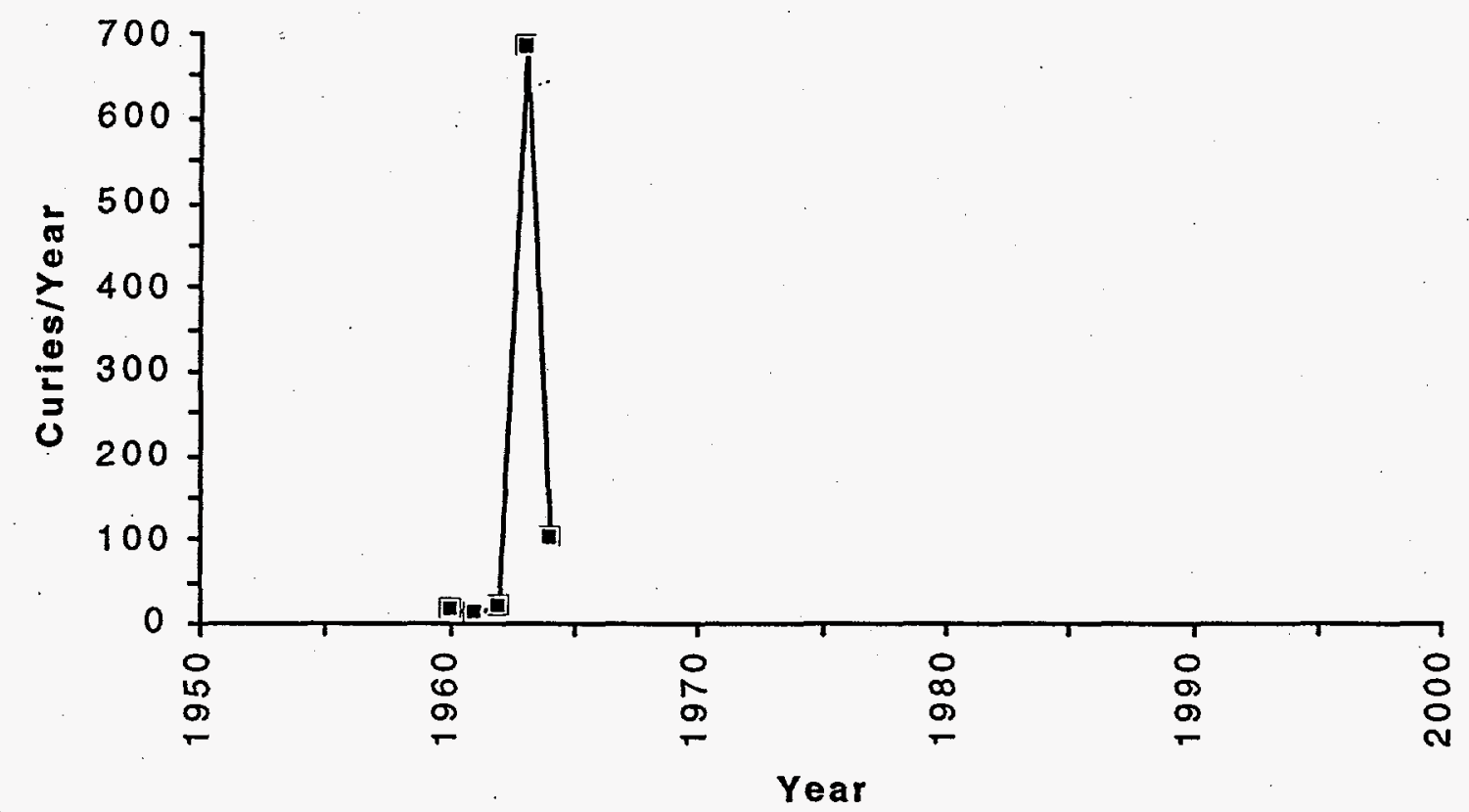

Figure 3.7. F Area Releases to Atmosphere
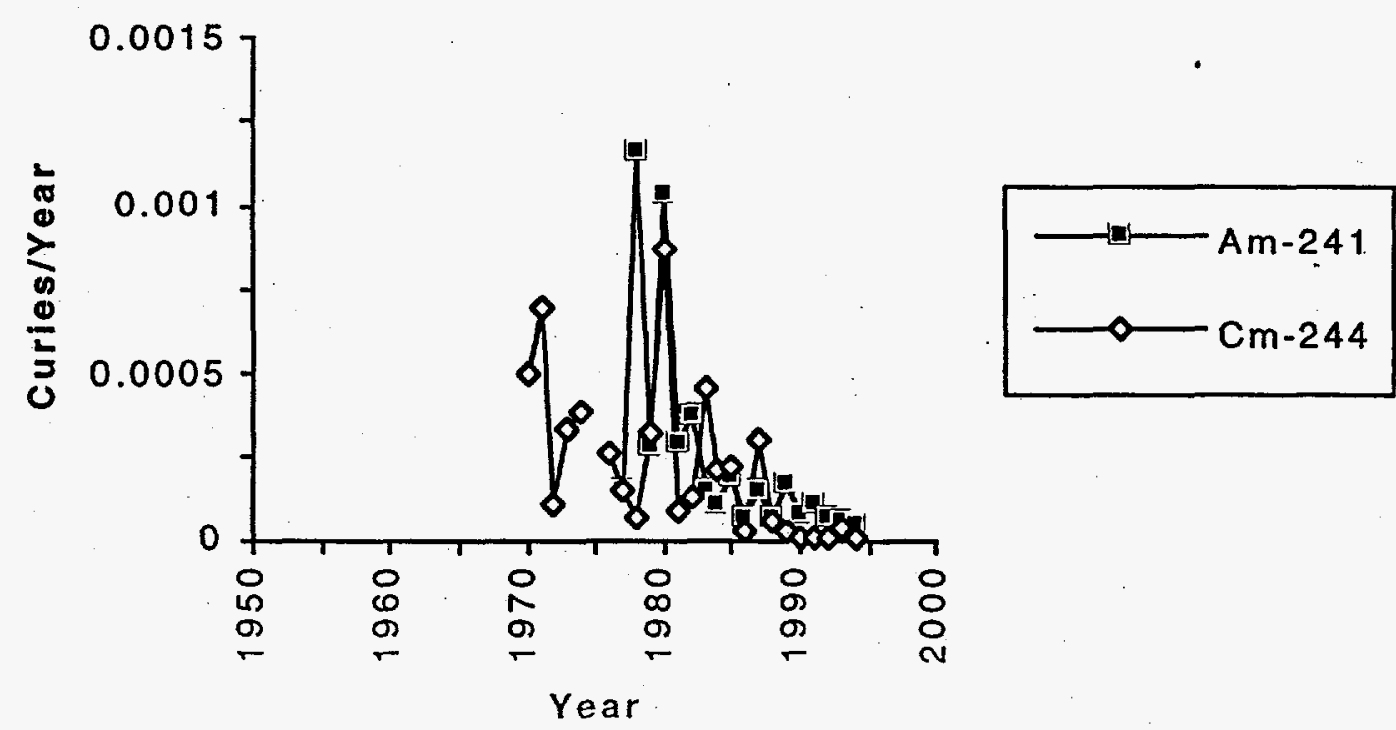
Figure 3.8. F-Area Releases to Basins

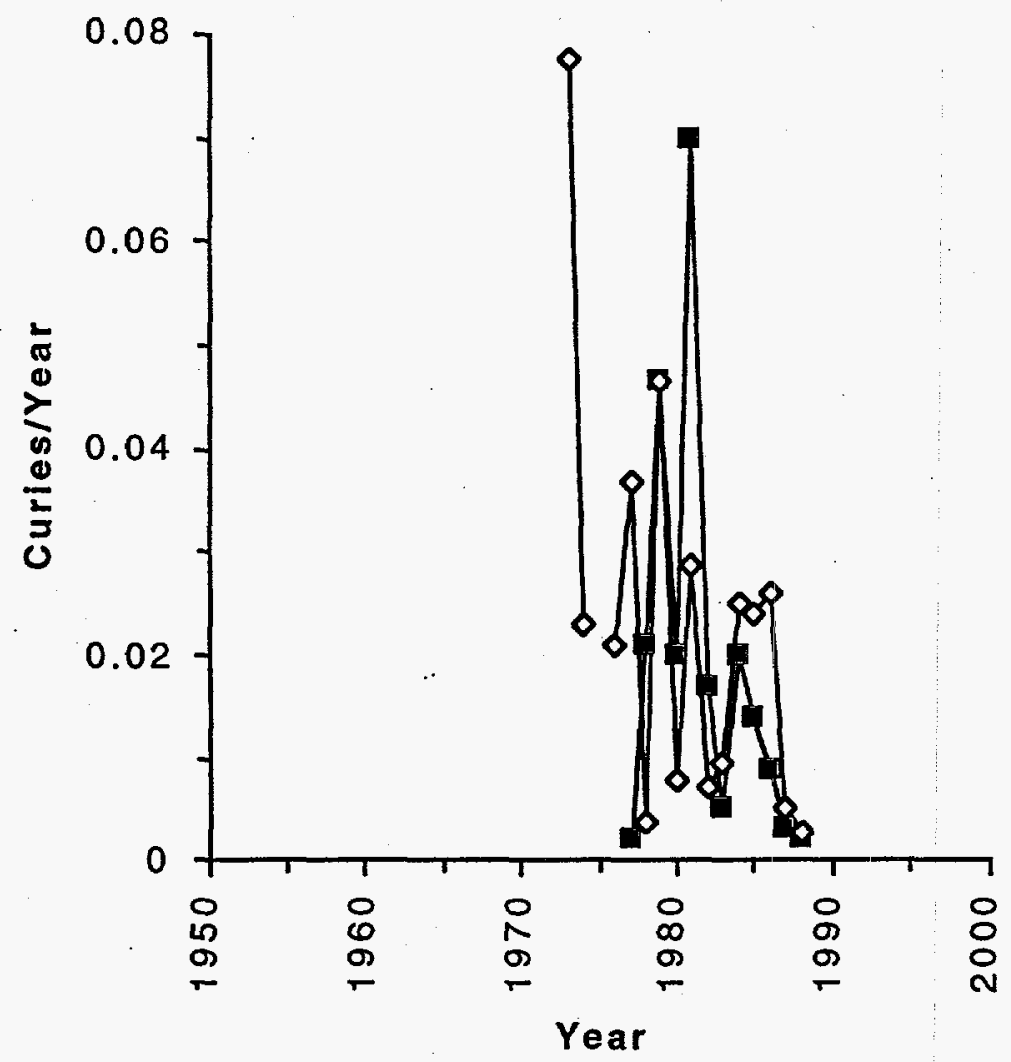

$\longrightarrow$ Am-241

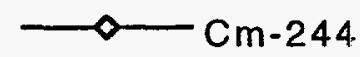

$\mathrm{Cm}-244$ 
Figure 3.9. H-Area Releases to Atmosphere

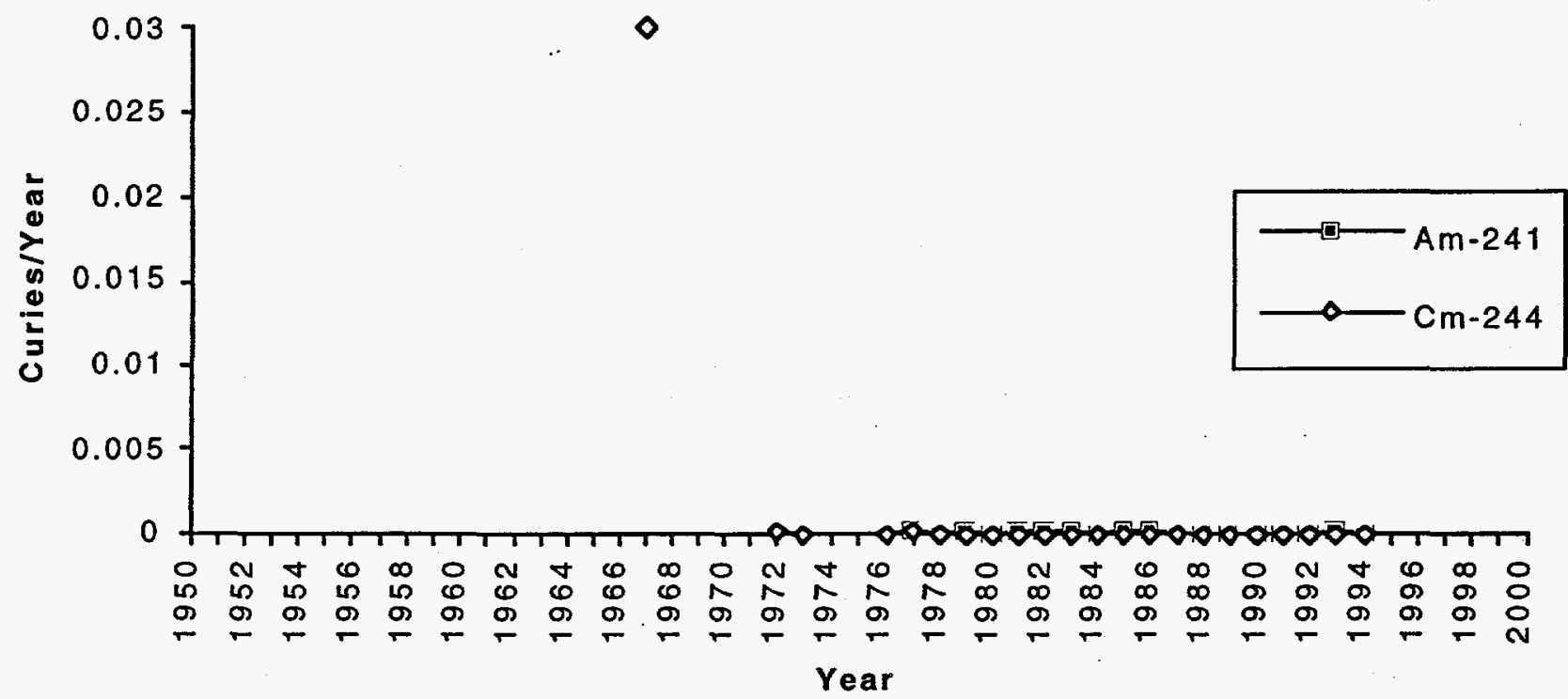

Figure 3.10. H-Area Releases to Basins

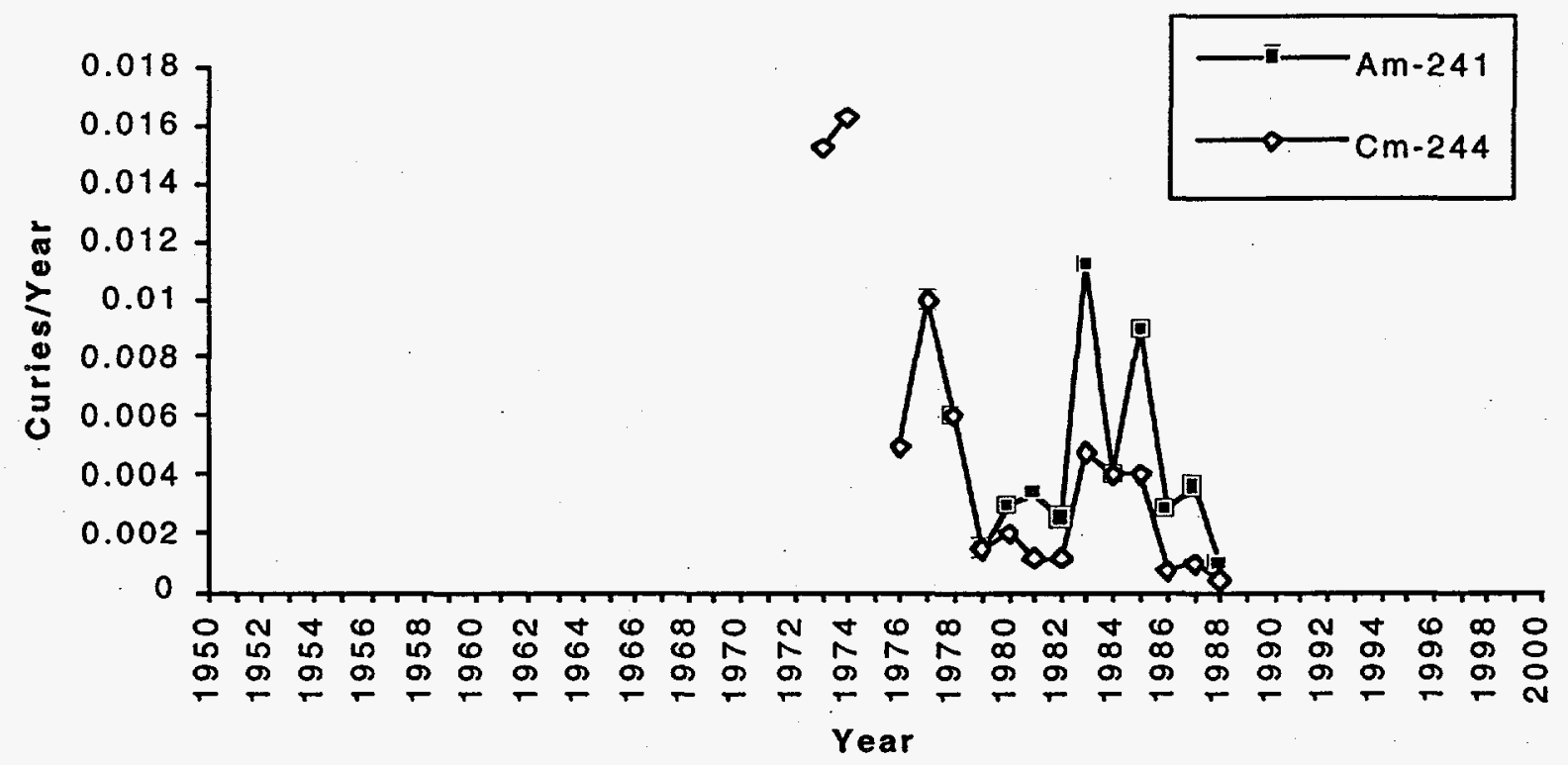


Figure 3.11. A-Area Cm-244 Releases to Atmosphere

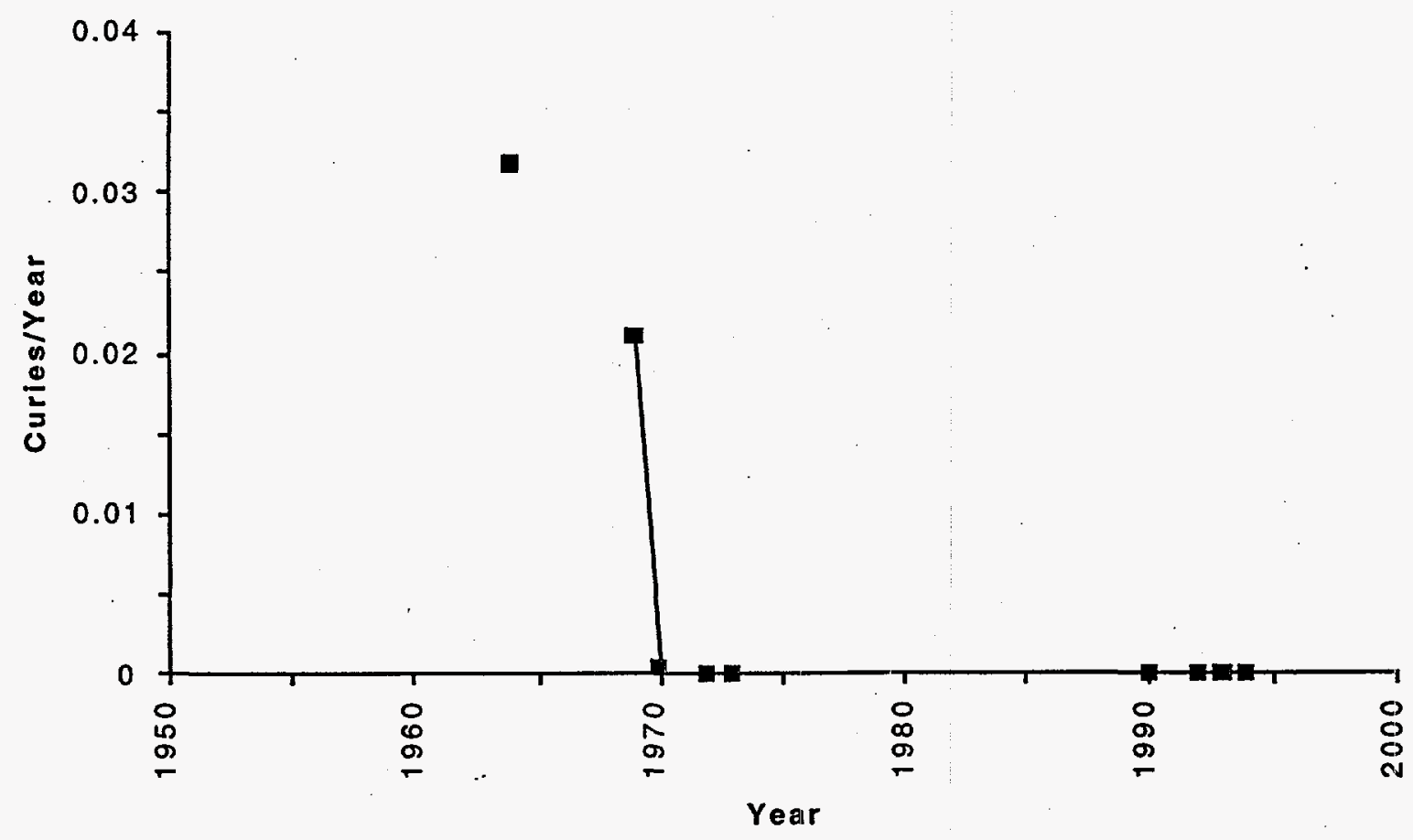


$\therefore \quad$ Chapter 4. Assessment of Dose/Risk

from SRS Neptunium, Americium, and Curium Releases

WSRC-TR-97-00266

\section{Chapter 4. Assessment of Dose/Risk from SRS Nep- tunium, Americium, and Curium Releases}

This chapter describes the health impacts associated with exposure to neptunium, americium, and curium. The methodology used to produce dose estimates is presented. The results of a dose assessment for releases during the 1954-1994 period are discussed. 
This page intentionally left blank 


\section{Relationship of Dose to Risk and Health Effects}

\section{lonizing Radiation}

Ionizing radiation is radiation that has enough energy to remove electrons from the atoms through which it passes. The interaction of ionizing radiation with biological systems can induce a series of chemical reactions that can cause permanent changes in the genetic material of cells. These changes (mutations) may cause abnormal functioning within the cell or may lead to cell death.

The nature of radiation-induced cellular changes depends on the magnitude of the dose and the rate at which it is received. For the low doses and dose rates encountered in the environment from SRS releases, the most significant potential effect is cancer induction.

This is believed to be a stochastic effect (i.e., an increase in dose increases the probability of the effect, but the severity of the effect is independent of the dose).

A characteristic of stochastic risks is the absence of a threshold. In other words, it is conceivable that any dose of radiation, no matter how small, might give rise to a cancer. On the other hand, there is no way to be certain that a given dose, no matter how large, will cause a cancer in an individual.

\section{Cancer Risk Estimates}

The most comprehensive estimates of cancer induction by exposure to ionizing radiation come from studies of the atomic bomb survivors at Hiroshima and Nagasaki. Less definitive studies include those of medical patients exposed to therapeutic and diagnostic radiation. Studies of laboratory animals have increased the understanding of dose-effect relationships. The International Commission on Radiological Protection (ICRP) has evaluated all these studies and concluded that the best estimate of lifetime risk of fatal cancer for members of the general population is approximately 500 cases per $1,000,000$ person-rem (ICRP 1991). This is equivalent to one case per 2,000 person-rem.

\section{Neptunium, Americium, and Curium Exposure and Dose to Man}

Neptunium is not a naturally occurring element, and our understanding of its metabolism comes from animal stud- ies. It is not readily absorbed from the gastrointestinal tract with only about $1 \%$ absorbed while the rest is excreted. Neptunium is assumed to distribute in the body in a manner similar to plutonium with most in the liver and bones. It remains in the liver with a half-life of 40 years and in bone with a half-life of 100 years (ICRP 1979a).

Americium has been distributed worldwide in fallout from nuclear weapons tests, but there is little human metabolic data. It is less readily absorbed from the gastrointestinal tract than is neptunium. Inhaled americium is cleared from the lung more rapidly than plutonium. Americium translocates to the liver and bone and is assumed to remain with the same biological half-lives as neptunium (ICRP 1979b).

Curium is chemically similar to americium and, based on animal studies, has been given the same metabolic characteristics (ICRP 1979b).

In 1988, DOE issued internal dose conversion factors to ensure that environmental doses are calculated in a consistent manner at all DOE facilities (DOE 1988). The factors, based on ICRP recommendations (ICRP 1979b), are used in conjunction with the models described later in this chapter to calculate all the doses reported in this document.

Future changes are anticipated in the dose calculation methodology. The ICRP has recently issued age-specific dose factors for ingestion of some of the more common isotopes and is developing age-specific dose factors for inhalation of radioisotopes (ICRP 1989).

\section{Models of Transport and Dose}

Except for tritium, most of the radioactive materials released from SRS have such low concentrations in the offsite environment that they are not detectable by conventional monitoring techniques. Therefore, radiation doses to offsite individuals and populations are calculated with mathematical models. These models use known transport mechanisms for atmospheric and liquid releases and known major pathways of exposure to man. Modeled atmospheric and aqueous dispersion are periodically verified using environmental tritium measurements (tritium is released during normal SRS operations).

The first models used at SRS to calculate offsite doses were developed by SRTC (Cooper 1975). These models, 
MREM (atmospheric releases) and RIVDOSE (liquid releases), were first used in 1972. In 1982, MREM and RIVDOSE were replaced with the more technologically advanced models now in use.

SRS annual offsite doses are currently calculated with the transport and dose models developed for the commercial nuclear industry (NRC 1977a; NRC 1977b). The models are implemented at SRS in the following computer programs:

\section{Atmospheric Releases}

- MAXIGASP calculates maximum dose to offsite individuals.

- POPGASP calculates offsite population collective dose.

\section{Liquid Releases}

- LADTAP II calculates both maximum and average doses to offsite individuals and collective dose to the offsite population.

MAXIGASP and POPGASP are SRTC-modified versions of the Nuclear Regulatory Commission (NRC) programs XOQDOQ (Sagendorf et al. 1982) and GASPAR (Eckerman et al. 1980). The modifications were made to meet the requirements for input of physical and biological data specific to SRS. The basic calculations in the XOQDOQ and GASPAR programs have not been modified. LADTAP II (Simpson and McGill 1980) is an essentially unaltered version of the NRC code of the same name. LADTAP XL, a spreadsheet version of LADTAP II, was used for dose modeling for this document.

\section{Modeling Atmospheric Dispersion of Radioactive Releases}

The routine atmospheric transport of radioactive materials from SRS is evaluated on the basis of meteorological conditions measured continuously at seven onsite towers. The towers relay wind speed, wind direction, and atmospheric stability information at 1.5 -second intervals-to SRTC via the WIND (Weather INformation and Display) system. A database of this information containing the 60-minute average values for the period 1987-1991 is accessed by the dispersion codes to estimate downwind concentrations of released radionuclides.

Historically, offsite doses have been calculated using HArea meteorology and assuming that releases occurred at the geographic center of the site. It has been demonstrated that using data from one of the other onsite meteorological towers has little effect on the maximum individual dose and no effect on the $80-\mathrm{km}$ population dose (Hamby and Parker 1991).

The dispersion of an atmospheric release from SRS is modeled using $X O Q D O Q$, which computes concentrations in the plume as a function of downwind distance and compass sector. The plume is depleted due to dry deposition and radioactive decay. At the user's option, plume concentrations can be reduced by taking into account the effluent's upward displacement, which results from thermal buoyancy and/or momentum effects. This option is not used at SRS (i.e., no credit is taken for plume rise).

The plume concentration information generated by XOQDOQ then is used by the dose modeling program GASPAR to estimate doses to offsite individuals and populations. GASPAR estimates doses from a number of pathways, which are illustrated in a general sense in Figure 4.1. The doses estimated by GASPAR are reported on a pathwayspecific basis, as follows:

- Plume-external dose from radioactive materials suspended in the atmosphere

- Ground-external dose from radioactive materials deposited on the ground

- Inhalation-internal dose from inhalation of radioactive materials present in the plume

- Vegetation-internal dose from consumption of contaminated crops

- Milk-internal dose from milk produced in a contaminated areá

- Meat-internal dose from consumption of meat produced in a contaminated area

XOQDOQ (Bauer 1991), GASPAR (Hamby 1992), MAXIGASP, and POPGASP (Hamby 1995) have undergone comprehensive reviews in association with the WSRC quality assurance requirements for software.

\section{MAXIGASP}

The calculations required by XOQDOQ and GASPAR to estimate maximum and average individual doses are performed at SRS using the computer program MAXIGASP. MAXIGASF calculates annual average ground-level air concentrations and 50-year committed doses at a number of points along the site boundary in each of 16 compass sectors.

The main outputs from the program are the maximum dose equivalents to an individual along the SRS perimeter. The maximally exposed individual is assumed to reside continuously at the location of highest exposure and to have living and eating habits that maximize his dose. These assump- 


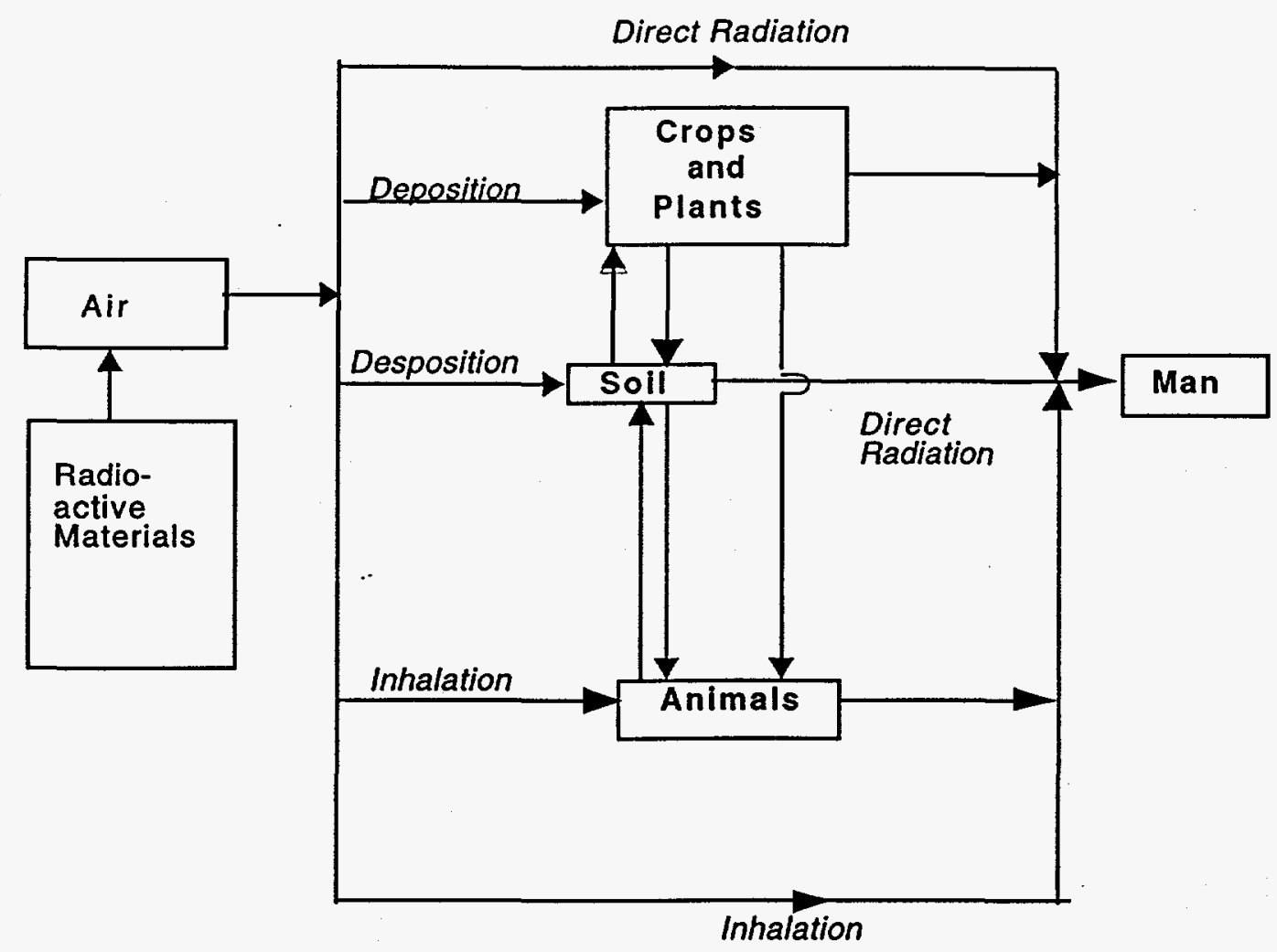

Figure 4.1. Simplified Pathways between Radioactive Materials Released to the Atmosphere and Man

tions provide a ceiling on doses from atmospheric releases, because no such individual is believed to exist.

The parameters used to calculate doses with MAXIGASP are presented in Table 4-1.

\section{POPGASP}

The calculations required by XOQDOQ and GASPAR to estimate population doses from atmospheric releases are performed at SRS using POPGASP. POPGASP calculates annual average ground-level air concentrations and annual doses for each of 160 regions ( 16 wind direction sectors at 10 distances per sector) within an 80-kilometer radius of the release location.

In addition to compass sector-specific meteorological information, POPGASP uses sector-specific data on population distribution and composition. Comparable data on milk, meat, and vegetable production/consumption also are used in the code. These data bases are extensive and are available for review in the SRS annual environmental reports. With respect to the human parameters used in POPGASP, the key values are shown in Table 4-1.

\section{Modeling Doses from Liquid Releases}

The consequences of liquid releases from SRS are modeled using LADTAP XI, a spreadsheet version of LADTAP II (Liquid Annual Doses To All Persons). The potential pathways of exposure from liquid releases to the environment are shown in Figure 4.2. The pathway-specific doses calculated by LADTAP are grouped into the following five categories:

- Potable drinking water-internal dose from consuming drinking water of Savannah River origin

- Sport fish and commercial fish-internal dose from consuming fish of Savannah River origin

- Salt water invertebrates-internal dose from consuming shellfish from estuaries of the Savannah River

- Recreation-external dose from recreation activities (boating, swimming, and shoreline) in and along the Savannah River

- Irrigation-internal dose from foods produced by irrigation with Savannah River water (there are no known users of the river for this purpose)

LADTAP XL estimates individual and population doses at specific downstream locations. The only removal mechanism included in the transport model as it is used at SRS is radioactive decay. No credit is taken for adsorption on stream sediments. 
Chapter 4. Assessment of Dose/Risk

Table 4-1. Site-Specific Parameters for Atmospheric Releases

\begin{tabular}{|c|c|}
\hline \multicolumn{2}{|l|}{ Population Group } \\
\hline $80-\mathrm{km}$ radius & $\begin{array}{c}555,100 \\
\text { (1980 Census) }\end{array}$ \\
\hline Exposure Pathway & $\begin{array}{l}\text { Maximum Individual } \\
\text { (MAXIGASP) }\end{array}$ \\
\hline Inhalation ( $\left.\mathrm{m}^{3 / y r}\right)$ & 8,000 \\
\hline \multicolumn{2}{|l|}{ Ingestion } \\
\hline Cow's milk (L/yr) & 230 \\
\hline Meat (kg/yr) & 81 \\
\hline $\begin{array}{l}\text { Leafy vegetables } \\
(\mathrm{kg} / \mathrm{yr})\end{array}$ & 43 \\
\hline $\begin{array}{l}\text { Fruits, grains, and oth- } \\
\text { er vegetables } \\
(\mathrm{kg} / \mathrm{yr})\end{array}$ & 276 \\
\hline \multicolumn{2}{|l|}{ External exposure } \\
\hline $\begin{array}{l}\text { Transmission factor } \\
\text { for shielding from } \\
\text { buildings }\end{array}$ & 0.7 \\
\hline Exposure Pathway & $\begin{array}{l}\text { General Population } \\
\text { (POPGASP) }\end{array}$ \\
\hline Inhalation $\left(\mathrm{m}^{3 / \mathrm{yr}}\right)$ & 8,000 \\
\hline \multicolumn{2}{|l|}{ Ingestion } \\
\hline Cow's milk (L/yr) & 120 \\
\hline Meat (kg/yr) & $\overline{43}$ \\
\hline $\begin{array}{l}\text { Leafy vegetables } \\
(\mathrm{kg} / \mathrm{yr})\end{array}$ & 21 \\
\hline $\begin{array}{c}\text { Fruits, grains, and } \\
\text { other vegetables } \\
(\mathrm{kg} / \mathrm{yr})\end{array}$ & 163 \\
\hline \multicolumn{2}{|l|}{ External exposure } \\
\hline $\begin{array}{l}\text { Transmission factor } \\
\text { for shielding from } \\
\text { buildings }\end{array}$ & 0.5 \\
\hline
\end{tabular}

One major difference between LADTAP II and LADTAP $\mathrm{XL}$ is the method of calculating population dose. LADTAP II uses only a fraction of the dose from fish caught in the Savannah River. The fraction is the ratio of the 80-kilometer harvest to the United States harvest. LADTAP XL assigns the dose from all fish to the population dose. LADTAP XL, used for dose calculations in this document, is conservative and reports the maximum population dose.
Table 4-2. Site-Specific Parameters for Liquid Releases

\begin{tabular}{|c|c|}
\hline $\begin{array}{l}\text { Maximally Exposed } \\
\text { Individual Dose Assessments } \\
\text { (LADTAP XL) }\end{array}$ & \\
\hline \multicolumn{2}{|l|}{ Site Parameters } \\
\hline $\begin{array}{l}\text { Savannah River flow rate } \\
\left(\mathrm{m}^{3} / \mathrm{sec}\right)\end{array}$ & $\begin{array}{l}\text { Measured annual } \\
\text { average }\end{array}$ \\
\hline $\begin{array}{l}\text { Transit time from } \\
\text { SRS to Savannah River (hr) }\end{array}$ & 24 \\
\hline Shore-width factor & $\overline{0.2}$ \\
\hline Human Parameters & $\begin{array}{l}\text { Maximum } \\
\text { Individual }\end{array}$ \\
\hline Water consumption (L/yr) & 730 \\
\hline Fish consumption (kg/yr) & 19 \\
\hline Shellfísh consumption (kg/yr) & 8 \\
\hline Shoreline recreation (hr/yr) & 23 \\
\hline Swimming $(\mathrm{hr} / \mathrm{yr})$ & 8.9 \\
\hline Boating (hr/yr) & 21 \\
\hline
\end{tabular}

One assumption inherent in the application of LADTAP XI to SRS releases is that liquid discharges undergo complete mixing in the Savannah River before reaching potentially exposed populations. This assumption is supported by repeated measurements indicating that complete mixing occurs in the river between the SRS and the Highway 301 sampling station (Arnett et al. 1994).

LADTAP XI generates maximum individual and population doses for all of the exposure pathways identified above. Though standard input values were provided in LADTAP II, SRS calculations are performed with site-specific information. Summary tables of principal input values used in the SRS version of LADTAP XL are shown in Table 4-2. Additional site specific parameters for liquid releases are shown in Table 4-3.

Radioisotope concentrations in the Savannah River are diluted by the inflow of streams downriver of SRS. Additional dilution occurs at the Beaufort-Jasper, South Carolina. water treatment plant due to the inflow of surface water and at the Port Wentworth, Georgia water treatment plant due to the close proximity of Abercorn Creek to the intake. Because tritium is readily measured in the processed water of each system, a derived river flow rate that allows better estimates of radionuclide concentrations at these treatment plants can be calculated. 
Table 4-3. Additional Site-Specific Parameters for Liquid Releases

\begin{tabular}{|l|c|}
\hline \multicolumn{2}{|c|}{$\begin{array}{c}\text { Average Individual/Population Dose Assessments } \\
\text { (LADTAP XL) }\end{array}$} \\
\hline $\begin{array}{l}\text { Site Parameters } \\
\text { (m/sec) }\end{array}$ & $\begin{array}{c}\text { Measured an- } \\
\text { nual average }\end{array}$ \\
\hline $\begin{array}{c}\text { Savannah River flow rate } \\
\text { Transit time from SRS } \\
\text { to Savannah River (hr) }\end{array}$ & 24 \\
\hline $\begin{array}{l}\text { Transit time from SRS } \\
\text { to water treatment plants (hr) }\end{array}$ & 72 \\
\hline $\begin{array}{l}\text { Retention time in } \\
\text { water treatment system (hr) }\end{array}$ & 24 \\
\hline Shore-width factor & 0.2 \\
\hline River dilution in estuary & 3 \\
\hline $\begin{array}{l}\text { Aquatic food harvest, edible por- } \\
\text { tions (kg/yr) }\end{array}$ & \\
\hline Sport fish & 35,000 \\
\hline Commercial fish & 2,700 \\
\hline Saltwater invertebrates & 390,000 \\
\hline Human Parameters & \\
\hline Water consumption (L/yr) & 370 \\
\hline Fish consumption (kg/yr) & 9 \\
\hline Shellfish consumption (kg/yr) & 2 \\
\hline Shoreline recreation (hr/yr) & 960,000 \\
\hline Swimming (hr/yr) & 160,000 \\
\hline Boating (hr/yr) & $1,100,000$ \\
\hline
\end{tabular}

Validation of Transport Models Using Monitoring Data

\section{Atmospheric Releases}

The radionuclide concentrations predicted by XOQDOQ are compared routinely with measured values of tritium concentrations in air to evaluate the performance of the code. (Tritium is the only radionuclide released by SRS that can be routinely detected offsite with conventional measuring techniques.) Predicted values tend to exceed observed values, yet not to a degree that would indicate an excessively conservative approach.
Other comparisons of predicted and measured concentrations have been made (Marter 1984; Simpkins and Hamby 1997) and have exhibited similar results. The data indicate that calculated concentrations of tritium in air generally are conservative estimates of actual offsite values.

\section{Liquid Releases}

Throughout the period 1954-1994, SRS liquid releases were dominated by tritium. Measured, rather than estimated, tritium concentrations therefore are used for the downriver locations that are the most important in terms of dose calculations:

- just below SRS

- at the Beaufort-Jasper water treatment plant

- at the Port Wentworth water treatment plant.

In addition to supplying measured tritium concentrations, such data also allow calculation of Savannah River dilution factors for these locations. The availability of accurate estimates of river dilution characteristics significantly enhances the ability to predict downriver concentrations of other radionuclides, such as neptunium.

\section{Impact of SRS Neptunium, Americium, and Curium Releases on the Offsite Population}

The computer codes MAXIGASP, POPGASP, and LADTAP $\mathrm{XL}$ have been used to calculate effective dose equivalents that have been theoretically received by segments of the offsite population from exposure to neptunium, americium, and curium over the course of site operations. The results are shown are in Tables 4-4 and 4-5 for atmospheric releases and Tables 4-6 and 4-7 for liquid releases.

\section{Doses from Atmospheric Releases}

As shown in Table 4-4, the largest annual effective dose equivalent theoretically received by the "maximum" adult at the site perimeter from a release of ${ }^{241} \mathrm{Am}$ was $0.004 \mathrm{mrem}$ and occurred in 1978.

Table 4-5 indicates that the largest annual dose from the release of ${ }^{244} \mathrm{Cm}$ was $0.05 \mathrm{mrem}$ and occurred in 1964 .

"Maximum" individuals are hypothetical persons who live at the SRS boundary and subsist on diets of locally produced 


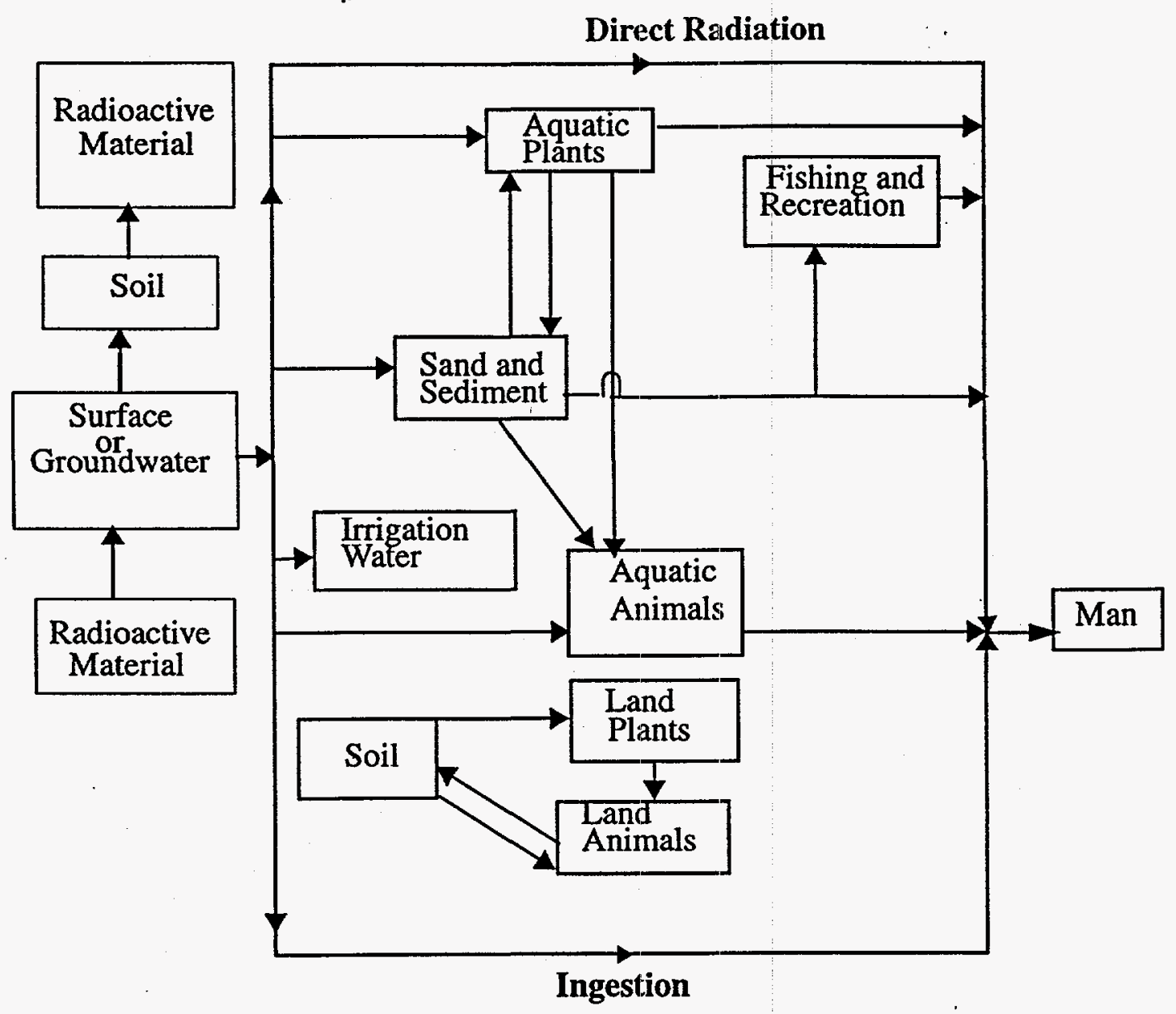

Figure 4.2. Simplified Pathways between Radioactive Materials Released to Groundwater or Surface Waters and Man 
milk, meat, and vegetables. No such individuals are known to exist. Nevertheless, if one examines the case of the maximally exposed adult individual living continuously at the site perimeter throughout the period 1954-1994, the cumulative effective dose equivalent from atmospheric releases of ${ }^{241} \mathrm{Am}$ has been estimated at $0.02 \mathrm{mrem}$ and from the release of ${ }^{244} \mathrm{Cm}$ was 0.15 mrem (see Table 4-4). The total dose from atmospheric releases was $0.17 \mathrm{mrem}$. These values are the upper bounding case and made a minor contribution to the overall dose received during that time period.

A person living in the Central Savannah River Area (CSRA) received an effective dose of approximately 12,000 mrem from exposure to natural sources of radioactivity and an additional 2,600 mrem from medical practices and various consumer products during the 40-year period (WSRC 1994). Therefore, the cumulative dose contribution to this individual from SRS atmospheric ${ }^{241} \mathrm{Am}$ and ${ }^{244} \mathrm{Cm}$ releases is about $0.001 \%$ of that received from sources unrelated to SRS.

Because the contribution of SRS ${ }^{241} \mathrm{Am}$ and ${ }^{244} \mathrm{Cm}$ releases to any individual's total radiation dose is so small, it is necessary to pool the radiation exposures from a given population if an assessment of potential health risks is desired. The population dose within an 80 -kilometer radius is the figure of merit frequently used to make such an assessment.

The population doses reported in Tables 4-4 and 4-5 are based on 1980 census data $(555,100$ people within $80 \mathrm{~km})$ and current meteorological and dose factor data. If it is assumed that this population has lived in the SRS vicinity throughout the period of site operations, the total collective effective dose potentially received by the population through 1994 would be 10 person-rem.

The risks associated with this collective dose are quite small. The risk estimate using ICRP factors for the number of excess fatal cancers potentially induced by a collective dose of 10 person-rem is 0.005 . Conversely, in the same population, at the current fatal cancer frequency of $16 \%$ (EPA 1989b), there will be about 90,000 spontaneous fatal cancers from all other causes. Therefore, it is impossible to demonstrate that a relationship exists between any of the cancer deaths occurring in this population and the releases of ${ }^{24 !} \mathrm{Am}$ and ${ }^{244} \mathrm{Cm}$ to the atmosphere.

\section{Individual Doses from Liquid Releases}

Dose equivalents potentially received by downstream consumers of Savannah River water and fish are shown in Tables 4-6 and 4-7. The release levels reflect contributions from all known effluents. Dose equivalents have been calculated for a "maximum" individual living just below SRS who subsisted on a diet of untreated Savannah River water and Savannah River fish. Such doses are believed to represent the bounding case for liquid releases. Drinking water doses also have been calculated for "maximum" individuals at both the downstream water treatment plants and for the populations served by these plants.

\section{${ }^{239} \mathrm{~Np}$}

The maximum annual dose occurred in 1963. The effective dose equivalent to the maximally exposed individual for that year has been estimated as $0.13 \mathrm{mrem}$. If the hypothetical "maximum" exposure conditions are used as the bounding case for the 40-year period of site operations considered in this report, the cumulative effective dose to such an individual would be about $0.23 \mathrm{mrem}$. Approximately $99 \%$ of this dose is due to eating fish from the Savannah River, and the remainder is due to drinking untreated river water.

\section{${ }^{244} \mathrm{Cm}$}

The maximum annual dose occurred in 1971. The effective dose equivalent to the maximally exposed individual for that year has been estimated as $0.09 \mathrm{mrem}$. If the hypothetical "maximum" exposure conditions are used as the bounding case for the 40-year period of site operations considered in this report, the cumulative effective dose to such an individual would be about $0.11 \mathrm{mrem}$. Approximately $60 \%$ of this dose is due to drinking untreated river water, and the remainder is due to eating fish from the Savannah River.

\section{Sum of All Doses}

The dose from the sum of the individual radionuclide doses is $0.34 \mathrm{mrem}$. Because this individual's dose from non-SRS sources of radiation for that same time period would have exceeded $14,000 \mathrm{mrem}$, it may be concluded that the contribution to downstream individual doses by SRS neptunium releases is insignificant.

\section{Collective Doses from Liquid Releases}

Collective or population doses to residents who drink Savannah River water, eat fish from the river, and eat salt- 
water invertebrates from the Savannah River estuary are reported in Tables 4-6 and 4-7.

Drinking water doses for users of the Beaufort-Jasper (50,000 customers) and Port Wentworth, (15,000 effective consumers). water treatment plants also have been estimated. Different terminology is used to describe the two populations to reflect the difference in their compositions (Hamby 1991). The Beaufort-Jasper plant services residential areas and therefore provides full-scale domestic water service. The Port Wentworth facility serves a commercial complex in which contact with treated Savannah River water is currently limited to industrial workers who consume tap water.

If the cumulative effective doses received by both water treatment plant populations are summed, the collective dose equivalent would be about 1.6 person-rem. Using the ICRP nominal risk factor, the predicted impact of this collective dose is an estimated 0.0008 excess fatal cancers in a population of 65,000 people- $-10,400$ of whom, at the current fatal cancer rate, are projected to succumb to cancer from all other sources.

The total population dose for liquid releases is the sum of the dose from the water treatment plant pathway (1.6 person-rem, 65,000 people) plus the dose due to other liquid pathways such as fish ( 49 person-rem, 550,000 people). The collective dose equivalent is 51 person-rem distributed among 615,000 people. The nominal risk factor predicts 0.03 fatal cancers in a population of 615,000 people98,000 of whom will die of cancer from other sources.

\section{Comparisons of Neptunium, Americium, and Curium Doses Near SRS with Applicable Regulations}

\section{Atmospheric Releases}

The highest hypothetical annual effective dose received by the maximally exposed individual because of atmospheric releases of ${ }^{241} \mathrm{Am}$ and ${ }^{244} \mathrm{Cm}$ from SRS was $0.05 \mathrm{mrem}$ in 1964 (see Tables 4-4 and 4-5). The current DOE and EPA annual limit for dose to members of the public because of atmospheric releases is $10 \mathrm{mrem}$ (DOE 1990 and EPA 1989a).

\section{Liquid Releases}

Neptunium doses from drinking water sources are evaluated based on the DOE and EPA annual drinking water standard of 4 mrem (DOE 1990 and EPA 1977). As shown in Tables 4-6 and 4-7, at no time during site operations has a drinking: water dose from SRS neptunium releases to the Savannah: River exceeded $0.1 \mathrm{mrem}$. The maximum dose was 0.08 mrem for Port Wentworth in 1963. It is important to note that the dose limits described above are meant to be applied to all releases of radioactivity, not just neptunium, americium, and curium. When the calculations are expanded to include all radionuclide releases, the relationship between SRS doses and the EPA dose limits described earlier remains valid. SRS is consistently a minor contributor to radiation dose in the SRS environment.

\section{Summary of Dosimetric Impacts}

The overall radiological impact of SRS neptunium, americium, and curium releases (1954-1994) on the offsite maximally exposed individual can be characterized by total doses of $0.17 \mathrm{mrem}$ (atmospheric) and $0.34 \mathrm{mrem}$ (liquid). During this same period, however, such an individual received a dose of approximately $14,000 \mathrm{mrem}$ from other sources of ionizing radiation present in the environment.

The impact of SRS americium and curium releases on offsite populations also has been evaluated. The total collective dose from atmospheric neptunium, americium, and curium releases (1954-1994) is estimated as 10 person-rem, distributed among 555,100 individuals. The total collective dose from liquid neptunium releases for the same period was 51 person-rem, distributed among the 555,100 individuals listed above and an additional 65,000 individuals who get their drinking water from the Savannah River. These collective doses are minor components of the doses received from other environmental sources.

Neptunium, americium, and curium releases from SRS have decreased dramatically in the last decade of site operations and present a negligible risk to the offsite environment and the population it supports. 


\section{References}

Arnett, M.W., L.K. Karapatakis and A.R. Mamatey, 1994, Savannah River Site Environmental Report for 1993, WSRC-TR-94-075, p. 79, Westinghouse Savannah River Company, Aiken, SC.

Bauer, L.R., 1991, Modeling Chronic Atmospheric Releases at the SRS: Evaluation and Verification of XOQ$D O Q(U)$, WSRC-RP-91-320, Westinghouse Savannah River Company, Aiken, SC.

Cooper, R.E., 1975, Computer Programs at SRL to Evaluate Environmental Effects of SRP Operations and Postu-

L lated Accidental Releases, DPST-75-384, Savannah River Laboratory, Aiken, SC.

DOE (U.S. Department of Energy), 1988, Internal Dose Conversion Factors for Calculation of Dose to the Public, DOE/EH-0071, Washington, DC.

DOE, 1990, Radiation Protection of the Public and Environment, DOE Order 5400.5, Washington, DC.

Eckerman, K.F., F.J. Congel, A.K. Roecklein, and W.J. Pasciak, 1980, User's Guide to GASPAR Code, NUREG0597, U.S. Nuclear Regulatory Commission, Washington, DC.

EPA (U.S. Environmental Protection Agency), 1977, National Interim Primary Drinking Water Regulations, EPA 570/9-76-003, Washington, DC.

EPA, 1989a, "National Emission Standards for Emissions of Radionuclides Other than Radon from Department of Energy Facilities," 40 CFR, Part 61, Subpart H, Washington, DC.

EPA, 1989b, "National Emission Standards for Hazardous Air Pollutants; Regulation of Radionuclides; Final Rule and Notice of Reconsideration," 40 CFR Part 61, Federal Register, Vol. 54, No. 240, Washington, DC.

Hamby, D.M., 1991, Land and Water Use Characteristics in the Vicinity of the Savannah River Site (U), WSRC-RP91-17, Westinghouse Savannah River Company, Aiken, SC.

Hamby, D.M., and M.J. Parker, 1991, Gaussian Dispersion and Dosimetric Modeling Sensitivity to Area-specific 1982-1986 Meteorological Data Collected at the Savannah River Site $(U)$, WSRC-RP-91-909, Westinghouse Savannah River Company, Aiken, SC.
Hamby, D.M., 1992, Verification of the GASPAR Dose Assessment Module Used in MAXIGASP and POPGASP, WSRC-RP-92-418, Westinghouse Savannah River Company, Aiken, SC.

Hamby, D.M., 1995, Verification of the MAXIGASP and POPGASP Computer Codes for Environmental Dose Assessment, WSRC-RP-94-522, Westinghouse Savannah River Company, Aiken, SC.

Hayes, D.W. and W.L. Marter, 1991, "Historical River Flow Rates for Dose Calculations," SRL-ETS-910257, Westinghouse Savannah River Company, Aiken, SC.

ICRP, 1979a, International Commission on Radiological Protection. Limits for Intake of Radionuclides by Workers, Oxford: Pergamon Press; ICRP Publication 30, Part 2.

ICRP, 1979b, International Commission on Radiological Protection. Limits for Intake of Radionuclides by Workers, Oxford: Pergamon Press; ICRP Publication 30, Part 1.

ICRP, 1989, International Commission on Radiological Protection. Age-Dependent Doses to Members of the Public from Radionuclides, Oxford: Pergamon Press; ICRP Publication 56.

ICRP, 1991, International Commission on Radiological Protection. Risks Associated with Ionizing Radiations, Oxford: Pergamon Press; ICRP Vol. 22, No. 1.

Marter, W.L., 1984, Environmental Dosimetry for Normal Operations at SRP, DPST-83-270, Rev. 1, Savannah River Laboratory, Aiken, SC.

NRC (U.S. Nuclear Regulatory Commission), 1977a, "Methods for Estimating Atmospheric Transport and Dispersion of Gaseous Effluents in Routine Releases from Light-Water-Cooled Reactors," Regulatory Guide 1.111, Rev. 1, Washington, DC.

NRC, 1977b, "Calculation of Annual Doses to Man from Routine Releases of Reactor Effluents for the Purpose of Evaluating Compliance with 10 CFR Part 50, Appendix I," Regulatory Guide 1.109, Rev. 1, Washington, DC.

Sagendorf, J.F., J.T. Goll, and W.F. Sandusky, 1982, XOQDOQ: Computer Program for the Meteorological Evaluation of Routine Effluent Releases at Nuclear Power Stations, NUREG/CR-2919, U.S. Nuclear Regulatory Commission, Washington, DC.

Simpson, D.B., and B.L. McGill, 1980, Users Manual for LADTAP II - A Computer Program for Calculating Radia- 
tion Exposure to Man from Routine Releases of Nuclear Reactor Effluents, NUREG/CR-1276, ORNL/TDMC-1, Oak Ridge National Laboratory, Oak Ridge, TN.

WSRC, 1994, Savannah River Site Environmental Report for 1993, Summary Report, WSRC-TR-94-076, Westinghouse Savannah River Company, Aiken, SC, p. 6.

Simpkins, A.A., and D.M. Hamby, 1997, "Predicted Versus Measured Tritium Oxide Concentrations at the Savannah River Site," Health Phys. 72(2):179-185; 1997. 
- Assessment of Neptumium, Americum, and Curium

in the Savannah River Site Environment (U)

WSRC-TR-97-00266

Table 4-4. Atmospheric Am-241 Releases and Dose

\begin{tabular}{|c|c|c|c|}
\hline Year & $\begin{array}{l}\text { Releases } \\
\text { (Ci) }\end{array}$ & $\begin{array}{l}\text { Maximum Individual Dose } \\
\text { at Boundary (mrem) }\end{array}$ & $\begin{array}{l}\text { Population Dose } \\
\text { (person-rem) }\end{array}$ \\
\hline \multicolumn{4}{|l|}{1954} \\
\hline \multicolumn{4}{|l|}{1955} \\
\hline \multicolumn{4}{|l|}{1956} \\
\hline \multicolumn{4}{|l|}{1957} \\
\hline \multicolumn{4}{|l|}{1958} \\
\hline \multicolumn{4}{|l|}{1959} \\
\hline \multicolumn{4}{|l|}{1960} \\
\hline \multicolumn{4}{|l|}{1961} \\
\hline \multicolumn{4}{|l|}{1962} \\
\hline \multicolumn{4}{|l|}{1963} \\
\hline \multicolumn{4}{|l|}{1964} \\
\hline \multicolumn{4}{|l|}{1965} \\
\hline \multicolumn{4}{|l|}{1966} \\
\hline \multicolumn{4}{|l|}{1967} \\
\hline \multicolumn{4}{|l|}{1968} \\
\hline \multicolumn{4}{|l|}{1969} \\
\hline \multicolumn{4}{|l|}{1970} \\
\hline \multicolumn{4}{|l|}{1971} \\
\hline \multicolumn{4}{|l|}{1972} \\
\hline \multicolumn{4}{|l|}{1973} \\
\hline \multicolumn{4}{|l|}{1974} \\
\hline \multicolumn{4}{|l|}{1975} \\
\hline \multicolumn{4}{|l|}{1976} \\
\hline 1977 & $3.4 \times 10^{-4}$ & $1.1 \times 10^{-3}$ & $6.5 \times 10^{-2}$ \\
\hline$\overline{1978}$ & $1.2 \times 10^{-3}$ & $3.9 \times 10^{-3}$ & $2.4 \times 10^{-1}$ \\
\hline 1979 & $3.6 \times 10^{-4}$ & $1.1 \times 10^{-3}$ & $6.8 \times 10^{-2}$ \\
\hline 1980 & $1.1 \times 10^{-3}$ & $3.4 \times 10^{-3}$ & $2.1 \times 10^{-1}$ \\
\hline 1981 & $4.9 \times 10^{-4}$ & $1.6 \times 10^{-3}$ & $9.5 \times 10^{-2}$ \\
\hline 1982 & $5.0 \times 10^{-4}$ & $1.6 \times 10^{-3}$ & $9.6 \times 10^{-2}$ \\
\hline 1983 & $2.6 \times 10^{-4}$ & $8.2 \times 10^{-4}$ & $4.9 \times 10^{-2}$ \\
\hline 1984 & $1.4 \times 10^{-4}$ & $4.6 \times 10^{-4}$ & $2.7 \times 10^{-2}$ \\
\hline 1985 & $4.3 \times 10^{-4}$ & $1.4 \times 10^{-3}$ & $8.2 \times 10^{-2}$ \\
\hline 1986 & $1.5 \times 10^{-4}$ & $4.9 \times 10^{-4}$ & $3.0 \times 10^{-2}$ \\
\hline 1987 & $2.0 \times 10^{-4}$ & $6.5 \times 10^{-4}$ & $3.9 \times 10^{-2}$ \\
\hline 1988 & $1.2 \times 10^{-4}$ & $3.8 \times 10^{-4}$ & $2.3 \times 10^{-2}$ \\
\hline 1989 & $2.0 \times 10^{-4}$ & $6.5 \times 10^{-4}$ & $3.9 \times 10^{-2}$ \\
\hline 1990 & $1.3 \times 10^{-4}$ & $4.1 \times 10^{-4}$ & $2.5 \times 10^{-2}$ \\
\hline 1991 & $1.5 \times 10^{-4}$ & $4.8 \times 10^{-4}$ & $2.9 \times 10^{-2}$ \\
\hline 1992 & $1.1 \times 10^{-4}$ & $3.6 \times 10^{-4}$ & $2.2 \times 10^{-2}$ \\
\hline 1993 & $1.4 \times 10^{-4}$ & $4.5 \times 10^{-4}$ & $2.7 \times 10^{-2}$ \\
\hline 1994 & $5.6 \times 10^{-5}$ & $1.8 \times 10^{-4}$ & $1.1 \times 10^{-2}$ \\
\hline Total & $6.1 \times 10^{-3}$ & $2.0 \times 10^{-2}$ & $1.2 \times 10^{0}$ \\
\hline
\end{tabular}


Chapter 4. Assessment of Dose/Risk

from SRS Neptunium, Americium, and Curium Releases

Table 4-5. Atmospheric Cm-244 Releases and Dose

\begin{tabular}{|c|c|c|c|}
\hline Year & Releases (Ci) & Maximum Individual Dose at Boundary (mrem) & Population Dose (person-rem) \\
\hline \multicolumn{4}{|l|}{1954} \\
\hline \multicolumn{4}{|l|}{1955} \\
\hline \multicolumn{4}{|l|}{1956} \\
\hline \multicolumn{4}{|l|}{1957} \\
\hline \multicolumn{4}{|l|}{1958} \\
\hline \multicolumn{4}{|l|}{1959} \\
\hline \multicolumn{4}{|l|}{1960} \\
\hline \multicolumn{4}{|l|}{1961} \\
\hline \multicolumn{4}{|l|}{1962} \\
\hline \multicolumn{4}{|l|}{1963} \\
\hline 1964 & $3.2 \times 10^{-2}$ & $5.2 \times 10^{-2}$ & $3.1 \times 10^{0}$ \\
\hline \multicolumn{4}{|l|}{1965} \\
\hline \multicolumn{4}{|l|}{1966} \\
\hline 1967 & $3.0 \times 10^{-2}$ & $5.0 \times 10^{-2}$ & $3.0 \times 10^{01}$ \\
\hline \multicolumn{4}{|l|}{1968} \\
\hline 1969 & $2.1 \times 10^{-2}$ & $3.5 \times 10^{-2}$ & $2.1 \times 10^{0}$ \\
\hline 1970 & $9.1 \times 10^{-4}$ & $1.5 \times 10^{-3}$ & $9.0 \times 10^{-2}$ \\
\hline 1971 & $7.0 \times 10^{-4}$ & $1.2 \times 10^{-3}$ & $6.9 \times 10^{-2}$ \\
\hline 1972 & $3.9 \times 10^{-4}$ & $6.4 \times 10^{-4}$ & $3.9 \times 10^{-2}$ \\
\hline 1973 & $3.8 \times 10^{-4}$ & $6.3 \times 10^{-4}$ & $3.8 \times 10^{-2}$ \\
\hline 1974 & $3.9 \times 10^{-4}$ & $6.4 \times 10^{-4}$ & $3.9 \times 10^{-2}$ \\
\hline \multicolumn{4}{|l|}{1975} \\
\hline 1976 & $3.3 \times 10^{-4}$ & $5.4 \times 10^{-4}$ & $3.3 \times 10^{-2}$ \\
\hline 1977 & $3.4 \times 10^{-4}$ & $5.6 \times 10^{-4}$ & $3.4 \times 10^{-2}$ \\
\hline 1978 & $1.4 \times 10^{-4}$ & $2.3 \times 10^{-4}$ & $1.4 \times 10^{-2}$ \\
\hline 1979 & $3.9 \times 10^{-4}$ & $6.4 \times 10^{-4}$ & $3.9 \times 10^{-2}$ \\
\hline 1980 & $9.0 \times 10^{-4}$ & $1.5 \times 10^{-3}$ & $8.9 \times 10^{-2}$ \\
\hline 1981 & $1.6 \times 10^{-4}$ & $2.7 \times 10^{-4}$ & $1.6 \times 10^{-2}$ \\
\hline 1982 & $1.7 \times 10^{-4}$ & $2.7 \times 10^{-4}$ & $1.6 \times 10^{-2}$ \\
\hline 1983 & $5.1 \times 10^{-4}$ & $8.3 \times 10^{-4}$ & $5.0 \times 10^{-2}$ \\
\hline 1984 & $2.6 \times 10^{-4}$ & $4.3 \times 10^{-4}$ & $2.6 \times 10^{-2}$ \\
\hline 1985 & $2.5 \times 10^{-4}$ & $4.1 \times 10^{-4}$ & $2.4 \times 10^{-2}$ \\
\hline 1986 & $2.8 \times 10^{-5}$ & $4.6 \times 10^{-5}$ & $2.8 \times 10^{-3}$ \\
\hline 1987 & $3.2 \times 10^{-4}$ & $5.3 \times 10^{-4}$ & $3.2 \times 10^{-2}$ \\
\hline 1988 & $6.7 \times 10^{-5}$ & $1.1 \times 10^{-4}$ & $6.6 \times 10^{-3}$ \\
\hline 1989 & $2.8 \times 10^{-5}$ & $4.6 \times 10^{-5}$ & $2.8 \times 10^{-3}$ \\
\hline 1990 & $2.0 \times 10^{-5}$ & $3.4 \times 10^{-5}$ & $2.0 \times 10^{-3}$ \\
\hline 1991 & $4.2 \times 10^{-5}$ & $7.0 \times 10^{-5}$ & $4.2 \times 10^{-3}$ \\
\hline 1992 & $2.3 \times 10^{-5}$ & $3.8 \times 10^{-5}$ & $2.3 \times 10^{-3}$ \\
\hline 1993 & $5.6 \times 10^{-5}$ & $9.3 \times 10^{-5}$ & $5.6 \times 10^{-3}$ \\
\hline 1994 & $1.6 \times 10^{-5}$ & $2.7 \times 10^{-5}$ & $1.6 \times 10^{-3}$ \\
\hline Total & $9.0 \times 10^{-2}$ & $1.5 \times 10^{-1}$ & $8.9 \times 10^{0}$ \\
\hline
\end{tabular}


Table 4-6. Stream Releases of Np-239 and Dose

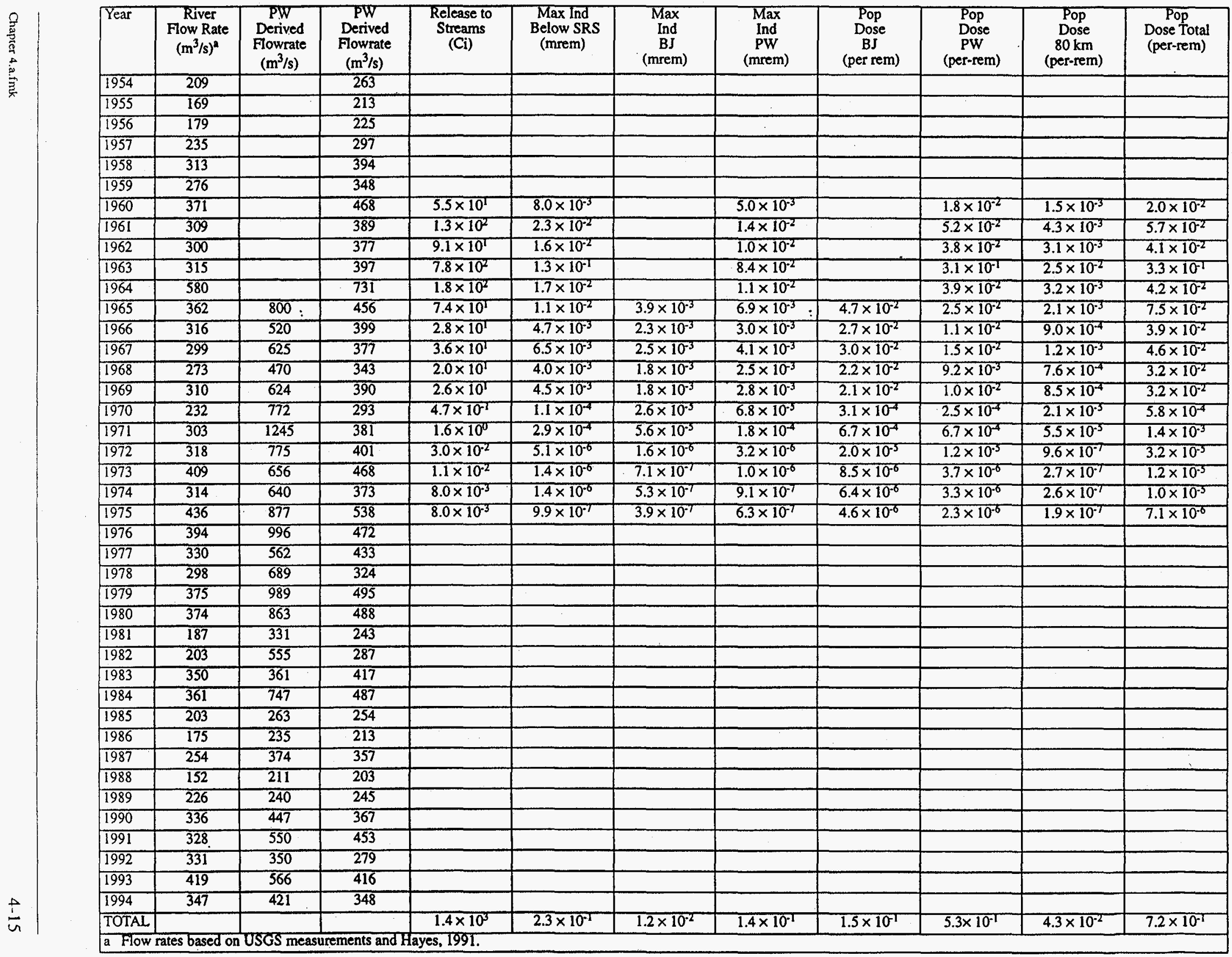


Table 4-7. Stream Releases of Cm-244 and Dose

\begin{tabular}{|c|c|c|c|c|c|c|c|c|c|c|c|}
\hline Year & $\begin{array}{c}\text { River } \\
\text { Flow Rate } \\
\left(\mathrm{m}^{3} / \mathrm{s}\right)^{\mathrm{a}}\end{array}$ & $\begin{array}{c}\text { PW } \\
\text { Derived } \\
\text { Flowrate } \\
\left(\mathrm{m}^{3} / \mathrm{s}\right)\end{array}$ & $\begin{array}{c}\text { PW } \\
\text { Derived } \\
\text { Flowrate } \\
\left(\mathrm{m}^{3} / \mathrm{s}\right)\end{array}$ & $\begin{array}{l}\text { Release to } \\
\text { Streams } \\
\text { (Ci) }\end{array}$ & $\begin{array}{l}\text { Max Ind } \\
\text { Below SRS } \\
\text { (mrem) }\end{array}$ & $\begin{array}{c}\text { Max } \\
\text { Ind } \\
\text { BJ } \\
\text { (mrem) }\end{array}$ & $\begin{array}{c}\text { Max } \\
\text { Ind } \\
\text { PW } \\
\text { (mrem) }\end{array}$ & $\begin{array}{c}\text { Pop } \\
\text { Dose } \\
\text { BJ } \\
\text { (per rem) }\end{array}$ & $\begin{array}{c}\text { Pop } \\
\text { Dose } \\
\text { PW } \\
\text { (per rem) }\end{array}$ & $\begin{array}{c}\text { Pop } \\
\text { Dose } \\
80 \mathrm{~km} \\
\text { (per rem) }\end{array}$ & $\begin{array}{c}\text { Pop } \\
\text { Dose Total } \\
\text { (per rem) }\end{array}$ \\
\hline 1954 & 209 & & 263 & & & & & & & & \\
\hline 1955 & 169 & & 213 & & & & & & & & \\
\hline 1956 & 179 & & 225 & & & & & & & & \\
\hline 1957 & 235 & & 297 & & & & & & & & \\
\hline 1958 & 313 & & 394 & & & & & & & & \\
\hline 1959 & 276 & & 348 & & & & & & & & \\
\hline 1960 & 371 & & 468 & & & & & & & & \\
\hline 1961 & 309 & & 389 & & & & & & & & \\
\hline 1962 & 300 & & 377 & & & & & & & & \\
\hline 1963 & 315 & & 397 & & & & & & & & \\
\hline 1964 & 580 & & 731 & & & & & & & & \\
\hline 1965 & 362 & 800. & 456 & & & & & & & & \\
\hline 1966 & 316 & 520 & 399 & ? & & & & & & & \\
\hline 1967 & 299 & $\overline{625}$ & 377 & & & & & & & & \\
\hline 1968 & 273 & 470 & 343 & & & & & & & & \\
\hline 1969 & 310 & 624 & 390 & $3.0 \times 10^{-2}$ & $8.5 \times 10^{-3}$ & $2.6 \times 10^{-3}$ & $4.1 \times 10^{-3}$ & $6.5 \times 10^{-2}$ & $3.0 \times 10^{-2}$ & $9.3 \times 10^{-1}$ & $1.0 \times 10^{0}$ \\
\hline 1970 & 232 & 772 & 293 & & & & & & & & \\
\hline 1971 & 303 & 1245 & 381 & $3.2 \times 10^{-1}$ & $9.4 \times 10^{-2}$ & $1.4 \times 10^{-2}$ & $4.6 \times 10^{-2}$ & $3.5 \times 10^{-1}$ & $3.4 \times 10^{-1}$ & $1.0 \times 10^{1}$ & $1.1 \times 10^{1}$ \\
\hline 1972 & 318 & 775 & 401 & $2.8 \times 10^{-2}$ & $7.7 \times 10^{-3}$ & $1.9 \times 10^{-3}$ & $3.7 \times 10^{-3}$ & $4.9 \times 10^{-2}$ & $2.8 \times 10^{-2}$ & $8.4 \times 10^{-1}$ & $9.2 \times 10^{-1}$ \\
\hline 1973 & 409 & 656 & 468 & $3.6 \times 10^{-3}$ & $7.8 \times 10^{-4}$ & $3.0 \times 10^{-4}$ & $4.2 \times 10^{-4}$ & $7.5 \times 10^{-3}$ & $3.1 \times 0^{-3}$ & $8.6 \times 10^{-2}$ & $9.6 \times 10^{-2}$ \\
\hline 1974 & 314 & 640 & 373 & & & & & & & & \\
\hline 1975 & 436 & 877 & 538 & & & & & & & & \\
\hline 1976 & 394 & 996 & 472 & & & & & & & & \\
\hline 1977 & 330 & 562 & $\overline{433}$ & & & & & & & & \\
\hline 1978 & 298 & 689 & 324 & & & & & & & & \\
\hline 1979 & 375 & 989 & 495 & & & & & & & & \\
\hline 1980 & 374 & 863 & 488 & & & & & & & & \\
\hline 1981 & 187 & 331 & 243 & & & & & & & & \\
\hline 1982 & 203 & 555 & 287 & & & & & & & & \\
\hline 1983 & 350 & 361 & 417 & & & & & & & & \\
\hline 1984 & 361 & 747 & 487 & & & & & & & & \\
\hline 1985 & 203 & 263 & 254 & & & & & & & & \\
\hline 1986 & 175 & 235 & 213 & & & & & & & & \\
\hline 1987 & 254 & $\overline{374}$ & 357 & & . & & & & & & \\
\hline 1988 & 152 & 211 & 203 & & & & 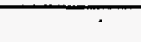 & & & & \\
\hline 1989 & 226 & 240 & 245 & & & & & & & & \\
\hline 1990 & 336 & 447 & 367 & & & & & & & & \\
\hline 1991 & 328 & 550 & 453 & & & & & & & & \\
\hline 1992 & 331 & 350 & 279 & & & & & & & & \\
\hline 1993 & 419 & 566 & 416 & & & & & & & & \\
\hline 1994 & 347 & 421 & 348 & & & & & & & & \\
\hline TOTAL & & & & $3.9 \times 10^{-1}$ & $1.1 \times 10^{-1}$ & $1.9 \times 10^{-2}$ & $5.4 \times 10^{-2}$ & $4.8 \times 10^{-1}$ & $4.0 \times 10^{-1}$ & $1.2 \times 10^{1}$ & $1.3 \times 10^{1}$ \\
\hline
\end{tabular}




\section{Additional Reading}

The following documents in the Radiological Assessment Program series are available to the public from

National Technical Information Service

U.S. Department of Commerce 5285 Port Royal Road

Springfield, VA 22161

Assessment of Activation Products in the Savannah River Site Environment WSRC-TR-95-0422

Assessment of Radiocarbon in the Savannah River Site Environment WSRC-TR-93-215

Cesium in the Savannah River Site Environment WSRC-RP-92-250

Also published in Health Phys. 67(3):233-244; 1994

Radioiodine in the Savannah River Site Environment WSRC-RP-90-424-2

Assessment of Mercury in the Savannah River Site Environment WSRC-TR-94-0218-ET

Assessment of Noble Gases in the Savannah River Site Environment WSRC-TR-95-219

Assessment of Plutonium n the Savannah River Site Environment WSRC-RP-92-879, Rev 1 Also published in Health Phys. 71(3):290-299; 1996

Assessment of Strontium in the Savannah River Site Environment WSRC-RP-92-984 -

Assessment of Technetium in the Savannah River Site Environment WSRC-TR-93-217

Assessment of Tritium

in the Savannah River Site Environment WSRC-TR-93-214

Uranium in the Savannah River Site Environment WSRC-RP-92-315 